$$
\text { UNIVERSIDADE DE SÃO PAULO }
$$

FACULDADE DE MEDICINA DE RIBEIRÃO PRETO

Estudo da resposta regenerativa do músculo sóleo de ratas bebês após procedimento de imobilização e reabilitação pelo alongamento.

Maikol Carlos Simões Gianelo

Ribeirão Preto 


\title{
Estudo da resposta regenerativa do músculo sóleo de ratas bebês após procedimento de imobilização e reabilitação pelo alongamento.
}

\section{Maikol Carlos Simões Gianelo}

Dissertação apresentada à Faculdade de Medicina de Ribeirão Preto - Universidade de São Paulo para obtenção do título de Mestre em Reabilitação e Desempenho Funcional

Orientadora: Prof ${ }^{a}$ Dra Ana Cláudia Mattiello-Sverzut

\author{
Ribeirão Preto
}


Autorizo a reprodução e divulgação total ou parcial deste trabalho, por qualquer meio convencional ou eletrônico, para fins de estudo e pesquisa, desde que citada a fonte. 


\section{FICHA CATALOGRÁFICA}

Gianelo, Maikol Carlos Simões

Estudo da resposta regenerativa do músculo sóleo de ratas bebês após procedimento de imobilização e reabilitação pelo alongamento.

Ribeirão Preto, 2014. (Versão Corrigida)

96 p. : il. ; $30 \mathrm{~cm}$

Dissertação de Mestrado, apresentada à Faculdade de Medicina de Ribeirão Preto/USP. Área de concentração: Ortopedia Traumatologia e Reabilitação.

Orientadora: Mattiello-Sverzut, Ana Cláudia.

1. Ratas recém-desmamadas. 2. Imobilização. 3. Alongamento muscular. 4. Sóleo. 5. Morfologia. 


\section{FOLHA DE APROVAÇÃO}

Nome: Maikol Carlos Simões Gianelo

Título: Estudo da resposta regenerativa do músculo sóleo de ratas bebês após procedimento de imobilização.

Dissertação apresentada à Faculdade de Medicina de Ribeirão Preto - Universidade de São Paulo para obtenção do título de Mestre em Reabilitação e Desempenho Funcional.

Aprovada em:

Banca Examinadora

Prof. Dr. Instituição:

Julgamento: Assinatura:

Prof. Dr. Instituição:

Julgamento: Assinatura:

Prof. Dr. Instituição:

Julgamento: Assinatura: 


\section{DEDICATÓRIA}

Aos meus pais Benedito Carlos Gianelo e Marilene Simões Gianelo, por ter me incentivado e dado força, compreensão e paciência durante todo o decorrer deste curso, que juntos conseguimos chegar ao final e minha noiva Francislene Pereira pela paciência que teve comigo ao longo do curso. 


\section{AGRADECIMENTOS}

Quero agradecer, a minha orientadora $\operatorname{Prof}^{\mathrm{a}} \mathrm{Dr}^{\mathrm{a}}$ Ana Cláudia MattielloSverzut. Uma pessoa extremamente humana e que em todos os momentos soube dar o apoio e incentivo para este trabalho e com paciência e sabedoria me orientou da melhor forma possível. "O verdadeiro orientador não está apenas em ensinar mas dar exemplos de suas atitudes". Aprendi muitas coisas e isso vou levar para o resto da vida. Muito obrigado por tudo!

Agradeço

À Universidade de São Paulo, pela oportunidade de mais um sonho em minha vida.

Ao Programa de Pós-Graduação Reabilitação e Desempenho Funcional, pelo fortalecimento da minha formação acadêmica.

Ao Prof. Dr. Luciano Neder Serafini, do Departamento de Patologia, por compartilhar todo o laboratório para a execução deste trabalho.

Às amigas Renata Jucá, Letícia, Keite, Camila, Cyntia Rogean de Jesus Alves de Baptista pela grande ajuda na realização deste trabalho

À amiga e técnica, Deise Lúcia Chesca, uma pessoa muito especial que me ajudou muito, principalmente por viabilizar processamentos realizados neste estudo, imprescindíveis para sua finalização, através de sua experiência profissional. Obrigado pelo seu apoio e amizade.

Ao grande amigo FELIPE DENIPOTTE, sempre disposto a me ajudar e que ao final deste trabalho se tornou um verdadeiro irmão. Obrigado amigo!!!

À(o) secretária(o) do Departamento de Reabilitação e Desempenho Funcional, Maria de Fátima, Samuel e às secretárias do Departamento de 
Patologia, Neide, Rosângela e Camila, por todo atendimento e informações concedidas durante a elaboração desta dissertação, feitos com muita solicitude.

À minha noiva, FRANCISLENE, que me apoiou em todos os momentos e perseverou junto comigo para a realização de mais um etapa. Obrigado por entender minhas ânsias e sonhos, e estar sempre ao meu lado.

Aos meus pais, BENEDITO E MARILENE, pelo incentivo e apoio em todas as etapas da minha vida e que com muito amor estiveram sempre orando por mim.

Ao meu DEUS, pelo Amor, Misericórdia e Paz para poder caminhar cada dia mais longe na Graça sob sua proteção e benção. 


\section{ATIVIDADES CIENTÍFICAS DESENVOLVIDAS COM OS DADOS DESTA DISSERTAÇÃO.}

Maio 2014. GIANELO MCS, POLIZZELO JC, CHESCA DL, MATTIELLOSVERZUT AC. Three days of rehabilitation by intermittent stretching does not minimize the effects of disuse on elements of the extracellular matrix and intermediate filaments of the soleus muscle of weanling rats. Artigo submetido no Brazilian Journal of Medical and Biological Research. (cópia do documento de confirmação da submissão do artigo - Anexo A). 


\section{RESUMO}

GIANELO, M.C.S. Estudo da resposta regenerativa do músculo sóleo de ratas bebes após procedimento de imobilização e reabilitação pelo alongamento. 2014. 96 f. Dissertação (Mestrado) - Faculdade de Medicina de Ribeirão Preto, Universidade de São Paulo, São Paulo, 2014.

Modelos de desusos do músculo esquelético como imobilização gessada, suspensão são frequentemente utilizados em grupos de pesquisas experimentais. Esse tempo de desuso por período prolongado pode determinar alterações significativas na citoarquitetura muscular. Este estudo teve como objetivo avaliar os aspectos morfológicos do músculo sóleo de ratas em desenvolvimento pósnatal que tiveram seus membros posteriores direitos imobilizados, e posteriormente foram submetidas ao protocolo passivo de alongamento (alongamento manual passivo intermitente), por um período de sete dias. Utilizouse 20 ratas da raça Wistar (Rattus Norvegicus Albinus) com 21 dias de idade, dividas em cinco grupos: Grupo Controle 21 dias (GC21- Animais com 21 dias), Grupo Imobilizado (GI- Animais de 21 dias que foram imobilizados por 7 dias), Grupo Imobilizado e Alongado (GIA- Animais de 21 dias que foram imobilizados por 7 e reabilitados pelo alongamento durante 3 dias) e Grupo Alongado (GAAnimais de 21 dias não imobilizados por 7 dias e posteriormente alongamentos durante 3 dias), Grupo Controle 30 (GC30 - Animais com 30 dias). Fragmentos dos músculo sóleo foi processado sob diferentes métodos histoquímicos, coloração hematoxilina-eosina e picro-sirius. As variáveis foram avaliadas inter-e intra-grupos através de técnicas estatísticas como: Teste de Kruskall Wallis e pós teste de Dunn. Conclusão: Os resultados indicaram que o músculo sóleo de ratas bebês sofreram modificações citoarquiteturais significativas quando 0 alongamento manual intermitente foi usado como recurso terapêutico após 7 dias de desuso do segmento posterior direito (imobilização em flexão plantar). Nos músculos imobilizados, ambas as proteínas (desmina e vimentina) tiveram seus conteúdos reduzidos em relação aos valores controle (21 ou 30 dias), indicando balanço negativo para o tecido pós-desuso. A quantidade dessas proteínas não 
foi modificada nos animais submetidos somente ao procedimento de alongamento intermitente. Os animais que sofreram imobilização e que foram reabilitados, a quantidade de desmina não aumentou significativamente, não atingindo valores similares ao grupo controle 30 dias. Esses dados sugerem que os filamentos de desmina necessitam de tempo superior a 3 dias de reabilitação por alongamento intermitente para restabelecerem a arquitetura intersticial das fibras e consequentemente favorecerem a transdução mecânica de sinais entre os meios intra e extracelular. Porém, o efeito citoarquitetural do alongamento sobre os filamentos intermediários deve ser acompanhado longitudinalmente e confirmados em adicionais estudos bioquímicos e moleculares.

Palavra chave: Imobilização, Vimentina, Desmina, Alongamento Intermitente, Colágeno. 


\section{ABSTRAT}

GIANELO, M.C.S. Study of the regenerative response of the soleus muscle of infant rats following immobilization and rehabilitation procedure by stretching. 2014. 96 f. Dissertação (Mestrado) - Faculdade de Medicina de Ribeirão Preto, Universidade de São Paulo, São Paulo, 2014.

Disuses models of skeletal muscle as immobilization, suspension are often used in experimental research groups. This time of disuse for a prolonged period can cause significant changes in muscle cytoarchitecture. This study aimed to evaluate the morphology of the soleus muscle of rats in postnatal development that had its members later immobilized rights, and subsequently were subjected to passive stretching protocol (passive manual stretching flashes), for a period of seven days. We used 20 Wistar rats (Rattus Norvegicus Albinos) race with 21 days of age , divided into five groups: Control Group (CG21- Animal 21 days ), Immobilized Group (IG- Animal 21 days that were immobilized for 7 days ), Immobilized and Stretched Group (ISG - Animal 21 days that were immobilized for 7 and rehabilitated by stretching for 3 days) and Stretched Group (SG -Animal 21 days not immobilized for 7 days and subsequently stretching for 3 days), Control Group (CG30 - Animals 30 days).Fragments of the soleus muscle was processed under different histochemical methods, hematoxylin - eosin staining and picro-sirius. Variables were evaluated inter - and intra - groups through statistical techniques such as Kruskall Wallis and Dunn's post test . Conclusion: The results indicated that the soleus muscle of rats were babies citoarquiteturais significant changes when the manual stretching intermittently been used as a therapeutic resource after 7 days of disuse of the right posterior segment ( immobilization in plantar flexion). The immobilized muscles, both proteins (desmin and vimentin ) content had decreased compared to control values (21 or 30 days), indicating negative after- tissue balance disuse. The amount of these proteins was not modified in animals subjected only to intermittent stretching procedure. The animals underwent 
immobilization have been rehabilitated and that the amount of desmin was not significantly increased, not reaching values similar to the control group 30 days. These data suggest that desmin filaments need to 3 days longer than the time for rehabilitation to restore the intermittent stretching interstitial fiber architecture and hence favor the mechanical transduction of signals between intra-and extracellular media. However, the effect of stretching on cytoarchitectural intermediate filaments should be followed longitudinally and confirmed in additional biochemical and molecular studies.

Keyword: Immobilization, vimentin, desmin, Intermittent Stretching, Collagen. 


\section{LISTA DE ILUSTRAÇÕES}

Figura 1. Localização da distrofina (Lovering \& Patrick ; 2003)........................... 28

Figura 2. Localização da Desmina no músculo liso, esquelético e liso (Costa et al., 2004)

29

Figura 3. Esquema da vimentina e interação com outras integrinas (IVASKA et al,

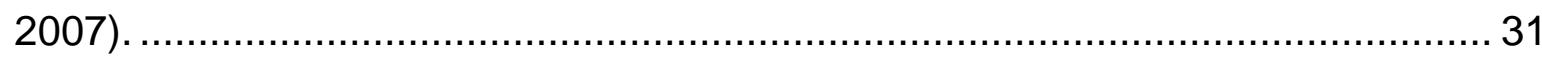

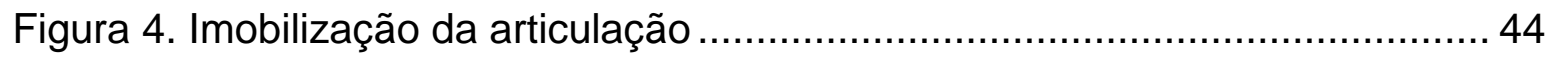

Figura 5 A e B: Modelo de imobilização proposto por BENEDINI-ELIAS et al., (2009). A: Parte superior, similar a uma camiseta de cotton. B: Parte inferior,

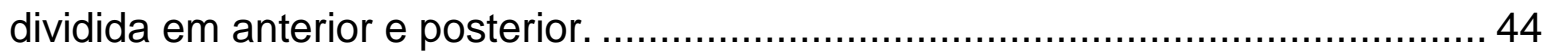

Figura 6. Alongamento manual passivo intermitente....................................... 45

Figura 7. Software Leica LAS V3.8 - Análise quantitativa dos filamentos intermedários 49

Figura 8. Software Leica LAS V3.8 - Análise gráfica dos filamentos intermedários 49

Figura 9. Software Leica LAS V3.8 - Contagem corpos de Inclusão .................... 51

Figura 10. Fotomicrografia do músculo sóleo, corado com HE. ( Barra: $25 \mu \mathrm{m}$ ) .... 54

Figura 11. Fotomicrografia do músculo sóleo, picrosirius ( Barra: $25 \mu \mathrm{m}$ ) …......... 56

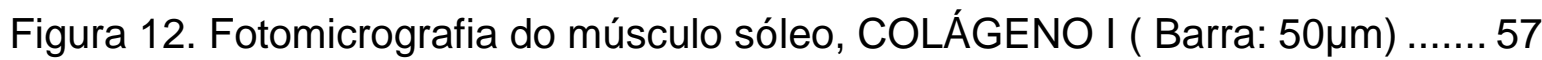

Figura 13. Fotomicrografia do músculo sóleo, COLÁGENO III ( Barra: $50 \mu \mathrm{m}$ ) ..... 58

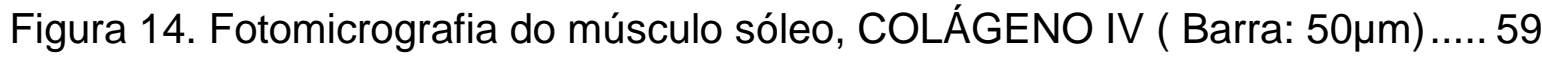

Figura 15. Fotomicrografia do músculo sóleo, DESMINA ( Barra: $25 \mu \mathrm{m}$ ) ............61 61

Figura 16. Fotomicrografia do músculo sóleo, VIMENTINA ( Barra: $25 \mu \mathrm{m}$ ) .......... 62

Figura 17. Fotomicrografias do músculo sóleo de animais dos grupos GCIn21.

GCFn30, com lâminas processadas pelos anticorpos rabbit polyclonal antidystrophin (fluorescência verde) e mouse monoclonal [ED1] anti-CD68 (fluorescência vermelha), marcação nuclear com DAPI

Figura 18. Fotomicrografias do músculo sóleo de animais dos grupos GI, GIA e GA, com lâminas processadas pelos anticorpos rabbit polyclonal anti-dystrophin (fluorescência verde) e mouse monoclonal [ED1] anti-CD68 (fluorescência vermelha), marcação nuclear com DAP 65 


\section{LISTA DE TABELAS}

Tabela 1. Divisão dos grupos experiemntais .................................................. 42

Tabela 2. Alterações histopatológicas por grupos ............................................ 53

Tabela 3. Análise semiquantitativa dos Colágenos I,III, IV e coloração especial

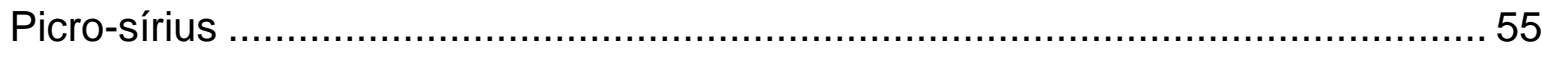

Tabela 4. Imunorreatividade para desmina e vimentina e densidade de macrófagos

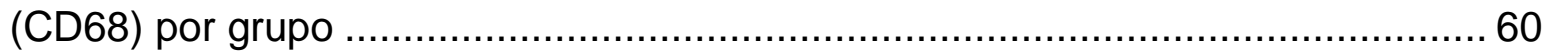




\section{LISTA DE ABREVIATURAS E SIGLAS}

$\begin{array}{ll}\text { AMPI } & \text { - Alongamento Manual Passivo Intermitente } \\ \text { AVD } & \text { - Atividade de vida diária } \\ \text { CETEA } & \text { - Comissão de Ética em Experimentação Animal } \\ \text { DAB } & \text { - Diaminobenzina } \\ \text { GC21 } & \text { - Grupo Controle Inicial 21 dias } \\ \text { GC30 } & \text { - Grupo Controle Final } 30 \text { dias } \\ \text { GI } & \text { - Grupo Imobilizado } \\ \text { GIA } & \text { - Grupo Imobilizado e Alongado } \\ \text { GA } & \text { - Grupo Alongado } \\ \text { HE } & \text { - Hematoxilina-Eosina } \\ \text { MHC } & \text { - Cadeia Pesada da Miosina } \\ \text { MEC } & \text { - Matriz extracelular } \\ \text { USP } & - \text { Universidade de São Paulo }\end{array}$




\section{LISTA DE SÍMBOLOS}

$\begin{array}{ll}\mathrm{m} / \mathrm{min} & - \text { metros por minuto } \\ \mathrm{Cm} & - \text { Centímetro } \\ \mathrm{mg} / \mathrm{kg} & - \text { miligramas por kilograma } \\ { }^{\circ} \mathrm{C} & - \text { graus Celsius } \\ \mathrm{Mm} & - \text { Milímetro } \\ \mathrm{M} & - \text { Metro } \\ \mathrm{G} & - \text { Grama } \\ \mathrm{S} & - \text { Segundo } \\ \mathrm{Ml} & - \text { Mililitro } \\ \mathrm{Kg} & - \text { Kilograma } \\ \mathrm{Min} & - \text { Minuto } \\ \mu \mathrm{m} & - \text { Micrômetro }\end{array}$




\section{SUMÁRIO}

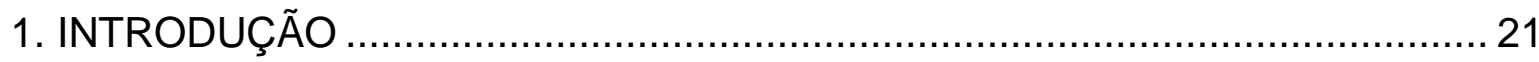

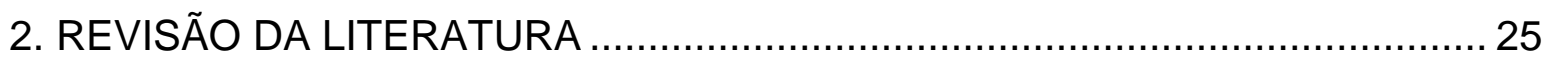

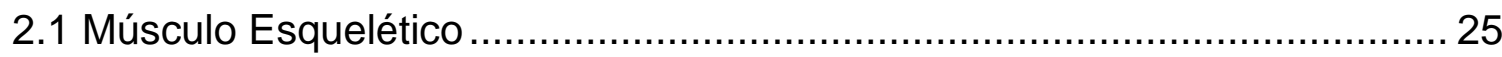

2.2. Efeitos da Imobilização no Sistema Músculo Esquelético .......................... 32

2.3 Efeitos do alongamento no músculo esquelético ...................................... 35

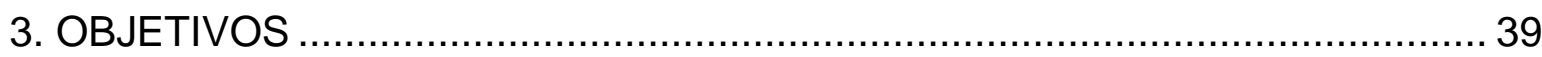

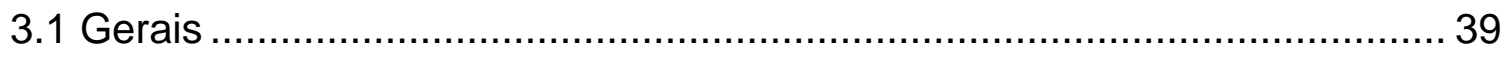

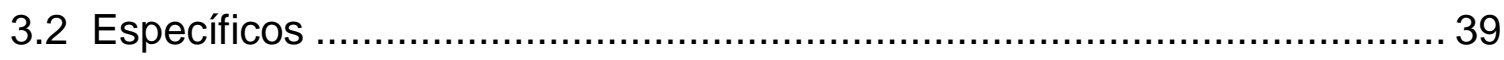

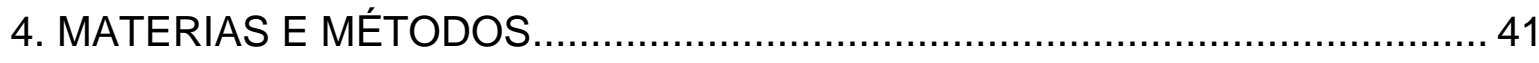

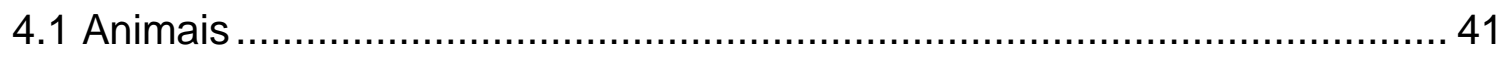

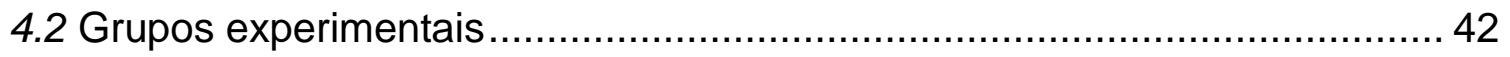

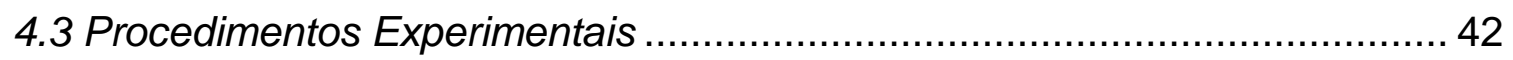

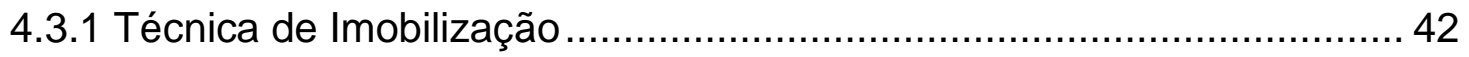

4.3.2 Técnica de alongamento manual passivo .......................................... 44

4.3.4 Obtenção dos Músculos ................................................................ 45

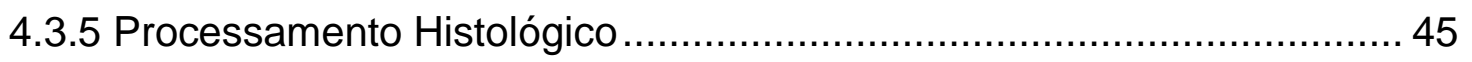

4.4 Processamentos imunoistoquímicos para colágeno Tipos I, III e IV, vimentina , desmina e imunofluorescência para distrofina e CD 68................. 46

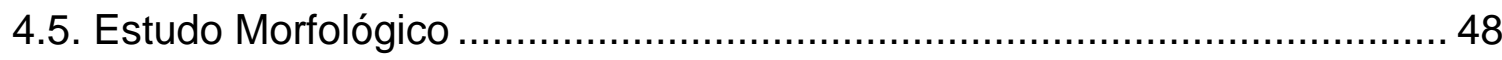

4.6 Análise semi-quantitativa para os colágenos dos tipos I, III e IV e Picro Sírius 48

4.7 Relação de imunorreatividade para desmina e vimentina entre os grupo. .. 48 4.8 Densidade de macrófagos e corpos de inclusão ….................................. 50 


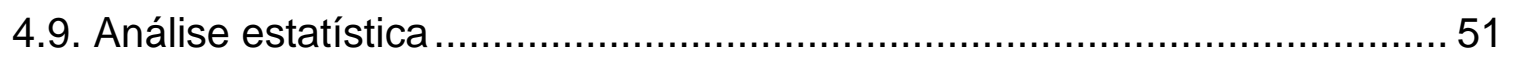

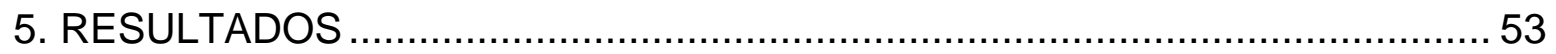

5.1 Análise histopatológica hematoxilina-eosina ............................................... 53

5.2 ANÁLISE DA COLORAÇÃO ESPECIAL - PICRO-SIRIUS, IMUNOISTOQUIMICA PARA COLÁGENO TIPO I, III E IV .............................. 55

5.4 Análise da imunoistoquimica para desmina, vimentina e CD68 ..................60

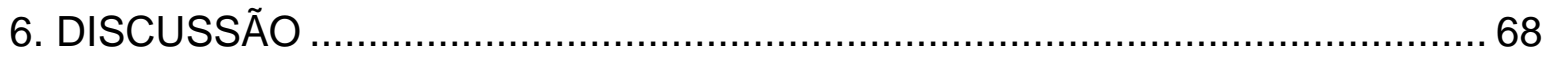

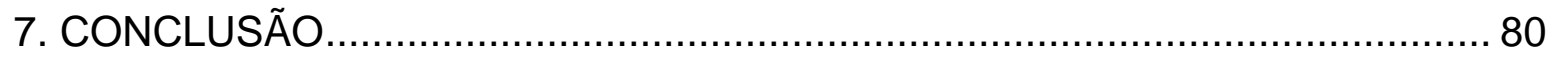

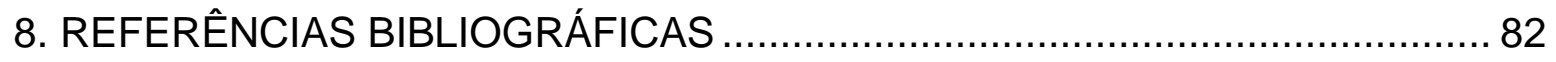

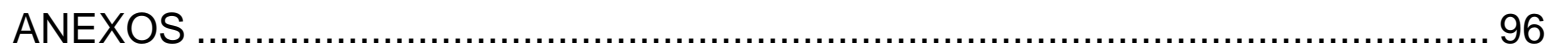

ANEXO A. Cópia da carta de confirmação da submissão do artigo intitulado "Three days of rehabilitation by intermittent stretching does not minimize the effects of disuse on elements of the extracellular matrix and intermediate filaments of the soleus muscle of rats babies" submetino no Journal of Cytology \& Histology em

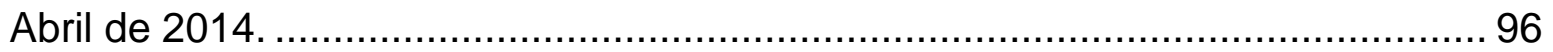


INTRODUCÃO 
INTRODUÇÃO - 21

\section{INTRODUÇÃO}

O sistema músculo esquelético se desenvolve durante a infância, e sofre maturação e diferenciação dos subtipos de fibras. Em modelos experimentais utilizando ratas no período entre a $2^{\underline{a}}$ e a $3^{\underline{a}}$ semana de vida, em que ocorre a saída do ninho, o término da fase de desmame, transição da inervação polineural para a mononeural e do fenótipo das fibras, correspondente à infância do animal, permitem comparações com tecido muscular de criança (BENEDINI-ELIAS et al., 2013; PUNKT; NAUPERT; ASMOSSEN, 2004).

Outras características importantes também são observadas como as mudanças na atividade neuromuscular, maturação da junção neuromuscular, mecanismo excitação-contração, aumento dos níveis dos hormônios tireoidianos (AGBULUT et al., 2003; PUNKT; NAUPERT; ASMOSSEN, 2004; SULLIVAN et al., 1995), e adaptações às diferentes demandas funcionais através das alterações estruturais já evidenciadas em diversos estudos experimentais utilizando o modelo de desuso por imobilização e exercícios físicos (CORNACHIONE et al., 2013; CAÇÃO-BENEDINI et al., 2013; THOMPSON, 2002; NATALLI, et al., 2008; CARVALHO; SHIMANO; VOLPON, 2002).

As respostas adaptativas do sistema muscular em maturação, após o período de desuso e frente à aplicação de protocolos de reabilitação segmentar, são raros na literatura científica (BENEDINI-ELIAS et al., 2013; MOURA-JUCÁ et al., 2014). Investigações que abordem as respostas adaptativas do tecido muscular em fase de crescimento e desenvolvimento, como observado na infância, 
INTRODUÇÃO - 22

são de extrema importância para a prescrição e fundamentação das técnicas abordadas na prática fisioterapêutica.

As respostas do tecido muscular em situações de tensão ou de cargas mecânicas reduzidas são variadas, dentre elas: aumento do sarcômero em série em casos de aumento da tensão e em cargas mecânicas reduzidas, a atrofia muscular, um processo altamente organizado e regulado por inúmeras alterações metabólicas, bioquímicas e estruturais que repercutem na funcionalidade dos músculos envolvidos (PETTE e STARON, 2000).

É sabido que as fibras musculares apresentam alta plasticidade durante 0 desenvolvimento, sofrendo alterações de funcionalidade e deste modo, podem sofrer alterações produzidas pelo desuso induzidas por imobilização em diferentes tipos de fibras musculares (PETTE e STARON, 2000; BENEDINI-ELIAS et al., 2013), tanto na posição encurtada (BENEDINI-ELIAS et al., 2013TABARY et al., 1972; KANNUS et al., 1998) como alongada (CORNACHIONE et al., 2013; TABARY et al., 1972; PATTULLO, et al., 1992). No músculo sóleo de gatos adultos, com predomínio de fibras lentas - tipo I, a imobilização na posição encurtada ao final de 7 dias, apresentou uma redução de $37 \%$ da sua massa (TABARY et al., 1972). Este resultado foi atribuído à rápida degradação da rede de fibrilas musculares e proteínas não colagênicas, levando à redução no diâmetro individual de cada fibra e diminuição no número de miofibrilas em paralelo (KASPER et al., 1993). Com a imobilização em posição de encurtamento, o comprimento ótimo das unidades contráteis é afetado, pois há redução do número de sarcômeros em série, a fim de manter o comprimento funcional ideal 
INTRODUÇÃO - 23

(COUTINHO et al., 2004). Por outro lado, a imobilização na posição alongada causa redução da massa muscular e aumento de tecido conjuntivo .No entanto, essa alteração é menos evidente quando comparada a imobilização em encurtamento, além de apresentar aumento de 17\% do número de sarcômero em série (TABARY et al., 1972; JÓZSA et al., 1990). A limitação na amplitude de movimento e a perda da extensibilidade do tecido conjuntivo também são determinadas pela imobilização (COOPER,1972) e a atrofia muscular é mais expressiva nos músculos de contração lenta em comparação aos de contração rápida, com possíveis alterações fenotípica (CORNACHIONE et al., 2013; SILVA et al., 2006).

Para minimizar esses efeitos e melhorar a funcionalidade no processo de reabilitação, o alongamento é um dos recursos terapêuticos muito utilizado na prática clínica, seja em adultos ou crianças. Os efeitos do alongamento em músculos encurtados vêm sendo estudado, porém, alguns aspectos técnicos, como a adoção da periodicidade da aplicação desse programa de treinamento e aspectos citoarquiteturais, merecem melhor detalhamento científico principalmente em tecidos na fase de maturação (BENEDINI-ELIAS et al., 2013; MOURA-JUCÁ et al., submetido; WILLIAMS; GOLDSPINK, 1973; WILLIAMS; GOLDSPINK, 1983). 
REVISÃO DA LITERATURA 


\section{REVISÃO DA LITERATURA}

\subsection{Músculo Esquelético}

O músculo esquelético é uma importante estrutura do corpo humano, responsável por acionar voluntária ou reflexamente, os segmentos corporais, além de promover um elevado grau de estabilidade nos complexos articulares. A função estabelecida ao sistema músculo esquelético vai depender de vários fatores como vias proprioceptivas intactas, inervação motora, mobilidade articular e a própria flexibilidade muscular.

O tecido músculo esquelético é revestido por tecido conjuntivo, denominado de epimísio o que envolve todo o músculo, perimísio envolvendo cada um dos fascículos, e o endomísio que reveste a fibra muscular (JUNQUEIRA; CARNEIRO, 2008).

O tecido conjuntivo intramuscular permite importantes ligações intercelulares e também entre a MEC (matriz extracelular) e as miofibrilas, pois durante os momentos de tensão, gerados por contração e alongamento, elas são as responsáveis pela absorção de energia, e contribui para a proteção do tecido, uma vez que é suficiente para manter a sua integridade física (JÄRVINEN et al., 2002).

Um dos constituintes do tecido conjuntivo é o colágeno, uma fibrila de elevada resistência à tração, produzida a partir da hidroxiprolina. È sabido que existem deferentes tipos de colágenos, classificados em colágeno fibrilar e nãofibrilar. Em ratos, os colágenos tipos I e III (fibrilar) são distribuídos a todos os três 
níveis de tecido muscular, e o colágeno tipo IV (não-fibrilar) está localizado em vasos e membrana basal do endomísio. O colágeno tipo $\mathrm{V}$ é o menor tipo, e é encontrado também no endomísio (GONDRET et al., 2007).

O colágeno tem sua estrutura estabilizada pelas formações covalentes do cross-link, que permitem a ligação entre suas moléculas com as miofibrilas e durante a maturação do colágeno. Os cross-links redutíveis são formados por condensações iniciais de alguns subprodutos e rapidamente são substituídos por cross-links não-redutíveis. O resultado dessa mudança é a maior estabilidade, diminuição da solubilidade da proteína e consequente aumento da resistência a algumas proteases, o que justifica a importância da presença de cross-link nãoredutível, sendo esta, capaz de modificar as propriedades mecânicas e bioquímicas, levando a redução na sustentação de força tênsil no tecido (KOVANEN, 2002).

Através dessas informações, entende-se, que as células do tecido conjuntivo são capazes de distinguir diferentes modos de estresse mecânico, como forças compressivas, tenseis e cisalhantes e deste modo, o estresse ou a redução da atividade pode influenciar a diferenciação dos componentes do tecido conjuntivo, e esse fato está relacionado com a mecanotransdução (KJÆER, 2004).

Formados por estruturas contráteis (sarcômeros) e não contrateis (proteínas estruturais), os músculos apresentam propriedades denominadas plásticas e elásticas (KISNER; COLBY, 1998). Estas propriedades permitem determinar quanto os tecidos são responsivos às forças externas. A fase elástica compreende na capacidade do tecido em receber uma carga e se alongar sem 
produzir deformação permanente. A fase plástica é aquela em que retirada a carga, ocorre deformação tecidual permanente, com rupturas ou microrrupturas dos componentes do tecido (CARVALHO; SHIMANO; PICADO, 2008). Para que adaptações aconteçam ao sistema músculo esquelético, estas duas fases devem estar presentes, porque as cargas tencionais exercem importante papel no mecanismo de mecanotransdução celular ( BURKHOLDER, 2008 ).

A mecanotransdução caracteriza o estresse mecânico que atua sobre uma célula, o que inicia, sinalizações intracelulares, o que pode promover 0 crescimento e a manutenção da sobrevivência celular. Em relação a este estresse mecânico, encontra-se as integrinas, que possuem importante papel na adesão entre os complexos presentes na membrana e matriz extracelular (MEC) do músculo, o que permite a transmissão de forças entre as regiões internas e externas da célula, com consequente conversão de sinais mecânicos em sinais químicos (LARSEN et al., 2006).

Além das integrinas, outras proteínas sarcolemais desempenham importante papel na mecanotrandução do músculo e tendão, destacando-se aquelas que formam o complexo glicoproteico da distrofina (CHOCKALINGAM et al., 2002). Segundo Lovering; Patrick (2003) a distrofina é uma proteína subsarcolemal que participa da comunicação entre as fibras musculares do citoesqueleto e a MEC, faz parte na transdução de sinais mecânicos, e sua localização esta entre as linhas Z e M do sarcômero conforme mostrado na Figura 1. 


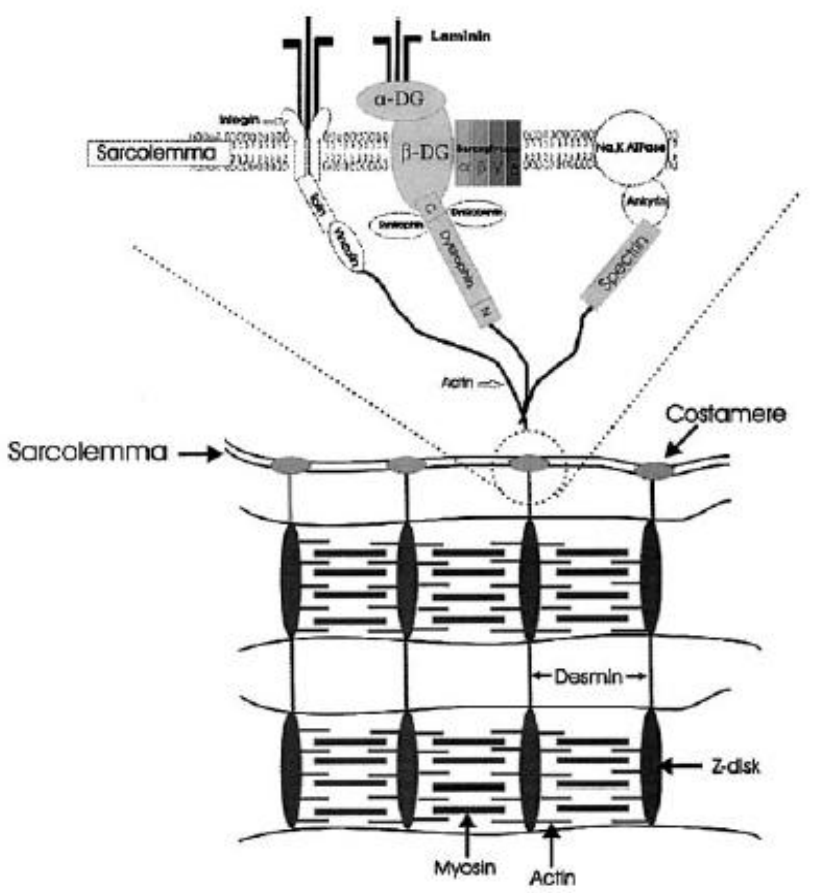

Figura 1. Localização da distrofina (Lovering \& Patrick ; 2003)

Quando submetido à tensão, o músculo é estimulado a alterar sua forma e tamanho. Essas mudanças são influenciadas diretamente pela quantidade e duração de força aplicada. Tendão, fáscia, fascículos, fibras, proteínas contrateis e o próprio sarcolema, são algumas das estruturas que oferecem resistência às forças externas e respondem de modo diferente a cargas tensionais (LIEBER; LEONARD; BROWN-MAUPIN, 2000).

São encontradas nas fibras musculares, as miofibrilas, feixes orientados ao longo do eixo celular, no interior do sarcoplasma, responsáveis em promover a contração muscular e as proteínas da MEC, que promovem a sustentação desse tecido (JÄRVINEN et al., 2005). As miofibrilas são compostas por sarcômeros, unidades funcionais do músculo. O sarcômero é formado por proteínas: actina, 
miosina, titina, tropomiosina, troponina e a interação entre essas proteínas, é muito importante para ocorrer a contração muscular.

A delimitação dos sarcômeros se dá entre duas linhas Z, sendo considerado a estrutura funcional básica da fibra muscular (WILMORE; COSTILL, 2001). Além dos microtubulos e microfilamentos, o tecido músculo esquelético também é constituído por filamentos intermediários, localizados na região extrasarcomérica entre as miofibrilas no nível dos discos Z, e miofibrilas periféricas do sarcolema e a membrana nuclear das miofibrilas e o sarcolema, sendo um desses filamentos intermediários localizados nessa região, a desmina (Figura 2).
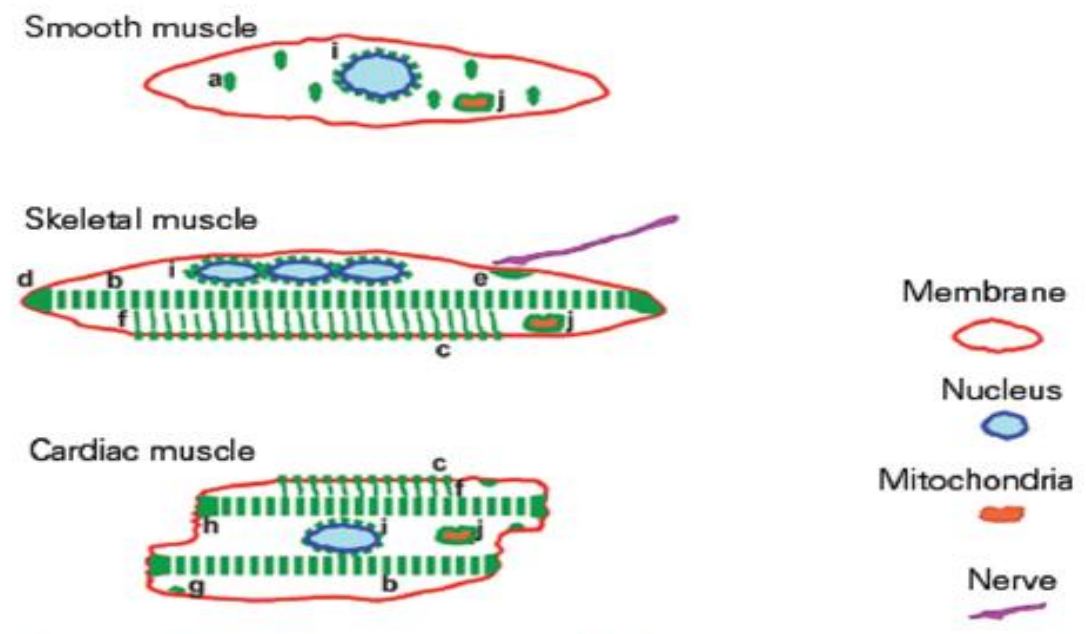

Figura 2. Localização da Desmina no músculo liso, esquelético e liso (Costa et al., 2004)

Os filamentos recebem esta denominação por apresentarem diâmetro de 8-10nm, que é intermediário ao diâmetro dos filamentos finos (actina, 6nm) e denso (miosina, 15nm) (YU, 2003). A função geral do citoesqueleto extrasarcomérico é a manutenção da forma celular e resistir ao estresse mecânico, localizados entre 
essas estruturas citadas anteriormente (microtubulo e microfilamento), com 7 e 11 nm. Os filamentos intermediários, compõem um sistema de estruturas filamentosas, no citoplasma e núcleo de células eucarióticas, diferente dos microfilamentos de actina, dos microtúbulos, extremamente insolúveis e de composição protéica (LAZARIDES, 1982).

Segundo Lazarides (1982), foram mencionados na literatura 5 tipos de filamentos intermediários nas células dos vertebrados : citoqueratinas (tecido epitelial), vimentina (tecido mesenquimal), desmina (tecido muscular), proteína glial fibrilar ácida astrócitos), neurofilamentos (neurônios).

A vimentina também é caracterizada como o principal filamento intermediário em fibroblastos encontrados em embrião de galinha e sua extração, em presença de detergente iônico, permite a obtenção de um polipeptídeo de 52$58 \mathrm{Kd}$, com a possibilidade de poder diferenciar imuno e bioquimicamente das outras classes de filamentos intermediários (FRANKE et al., 1978). Alguns trabalhos mostram que a vimentina (figura 3) e a desmina coexistem, durante toda a miogênese, porém a vimentina predomina em estágios iniciais e a desmina em estágios mais tardios (LAZARIDES, 1982; CHOU YH; ROSENVAR E; GOLDMAN RD, 1989).

Devido ao alto grau de insolubilidade da vimentina, sugere-se que uma de suas funções na estrutural no citoplasma, seja a organização da posição do núcleo e do fuso mitótico, durante a vida da célula e que durante a mitose, a vimentina sofre fosforilação do seu domínio amino terminal e se dispersa em 
agregados, contendo formas filamentosas (CHOU YH; ROSENVAR E; GOLDMAN RD, 1989).

No tecido músculo esquelético também existem outras estruturas importante para seu pleno funcionamento, como a cadeia pesada de miosina (MHC). A MHC é a principal proteína estrutural e reguladora que serve de motor molecular no controle das propriedades contráteis intrínsecas da fibra muscular, e pelas suas diferentes isoformas, permite caracterizar o músculo esquelético. Conhecem-se 4 isoformas de MHC expressas em níveis elevados nos músculos de roedores adultos: $\mathrm{MHCl}$ (ou $\beta$ Cardíaca), $\mathrm{MHC}$ Ilc, $\mathrm{MHClld} / \mathrm{x}$ e $\mathrm{MHC}$ Ilb. (FERREIRA et al., 2004).

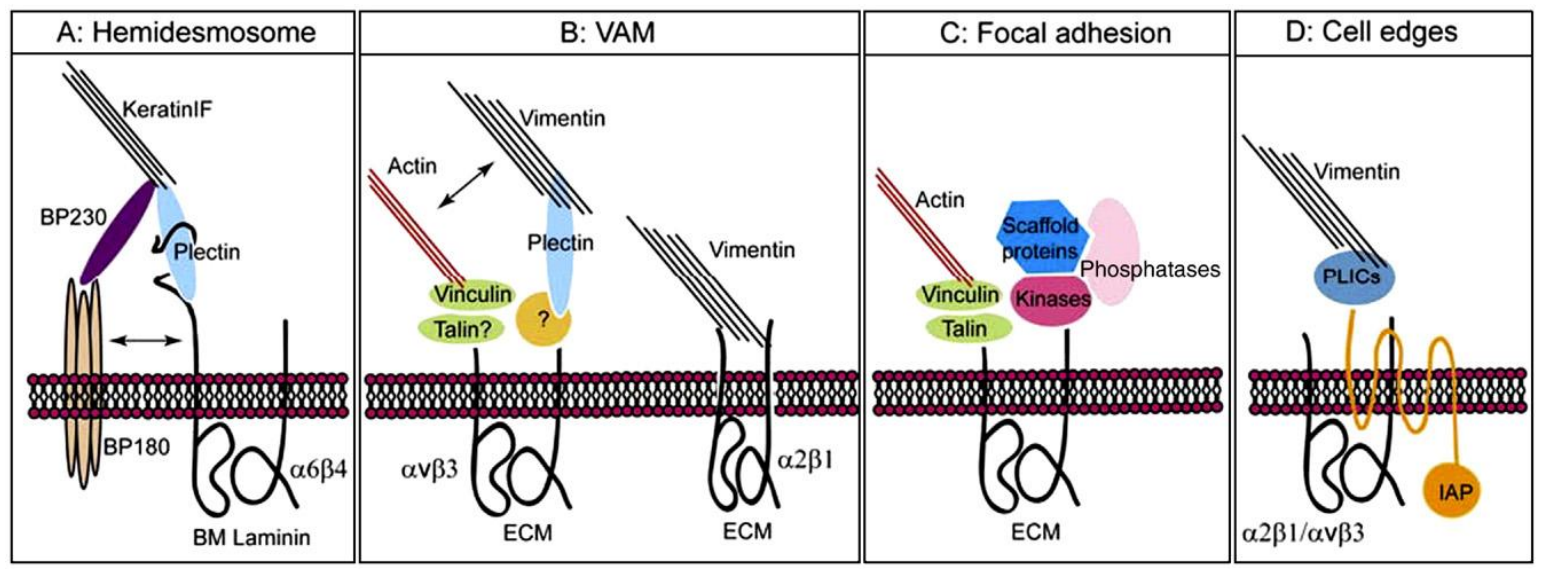

Figura 3. Esquema da vimentina e interação com outras integrinas (IVASKA et al, 2007).

A isoforma $\mathrm{MHCl}$ é expressa em fibras de contração lenta denominadas tipo I, ricas em mitocôndrias. As fibras do tipo II podem ser subdivididas em Ila, IIx/d e llb, que correspondem à cadeia pesada de miosina $\mathrm{MHC}$, as isoformas MHClla, MHCllx/d e MHCllb respectivamente (PETTE; PEUKE; STARON, 1999, TALMADGE, 2000). 
Essas fibras podem ser chamadas de puras, visto que expressam um único tipo de MHC. Quando as fibras apresentam uma combinação heterogênea de isoformas (Ex: MHCllb + MHC IIx/d) são classificadas como híbridas. O predominio dos subtipos pode variar de músculo para músculo, MHC Ilb, MHCIlx/d,MHCl, MHC Ila, ora possuirá predomínio llb ora apresentará predomínio IIx/d ( PETTE; PEUKER;STARON, 1999).

Essa classificação das fibras musculares em puras e híbridas, é baseada nas diferentes labilidades da atividade da adenosina trifosfatase miofibrilar (mATPase) contida na miosina (GONGRET et al., 2007). O fenótipo das fibras musculares é alterado em diversas condições, como aumento ou redução da atividade neuromuscular e/ou carga mecânica (TALMADGE, 2000), alterações hormonais, idade, entre outros fatores (PETTE; PEUKER; STARON, 2000). É sabido que transições entre tipos de fibras musculares ocorrem, porém com algumas observações. A transição das fibras rápidas para lentas não é muito encontrada, por exemplo $\mathrm{MHCllb--MHCl}$, sem passar pela $\mathrm{MHClla}$ e $\mathrm{MHCllx} / \mathrm{d}$ (PEUKER, 1998).

\subsection{Efeitos da Imobilização no Sistema Músculo Esquelético}

O processo de imobilização é muito utilizado em casos de fraturas ósseas, lesões articulares, ligamentares, musculares, tanto em tratamentos pós cirúrgicos como conservadores (HERBERT; XAVIER, 2009). A proliferação de tecido conjuntivo, degradação de miofibrilas e proteínas musculares (atrofia), diminuição do número de mitocôndrias, decréscimo na densidade capilar, redução na 
capacidade de gerar força e da resistência da musculatura, redução de sarcômeros em série, são adaptações importantes que ocorrem no músculo esquelético submetido à imobilização e procedimentos de desuso (DURIGAN et al., 2006, MATTIELLO-SVERZUT et al., 2006; KANNUS et al.,1998; SILVA et al., 2006; COUTINHO et al., 2004; WILLIANS et al., 1998; OKITA et al., 2001; BALDWIN et al., 1994). Essas alterações podem ser observadas no eixo longitudinal (encurtamentos) e transversal (atrofia).

Clinicamente, essas adaptações resultarão em fraqueza e restrição de movimento articular, alterando a capacidade funcional em realizar movimentos, e consequentemente a qualidade de vida dos indivíduos nas atividades de vida diária (AVDs).

Segundo Durigan et al. (2006), após três dias de imobilização, há aumento na densidade de tecido conjuntivo no músculo sóleo, devido a redução da massa e comprimento muscular. Também foi observado rápida degradação de miofibrilas e proteínas não colagênicas, levando a diminuição do diâmetro de cada fibra muscular. Após sete dias há uma redução de 37\% da massa muscular (GAMRIN et al., 1998) e após três semanas, há redução de $69 \%$ da área das fibras do músculo sóleo em ratos (KANNUS et al., 1998).

Vários modelos de desuso foram desenvolvidos para estudar a transição das fibras musculares, como imobilização em posição de encurtamento muscular, suspensão pela cauda, suspensão pela cauda para simular a microgravidade. Estes estudos demonstram redução de fibras do tipo I (CAIOZZO et al., 1996, correspondendo a diminuição na concentração relativa de $\mathrm{MHCl}$ e aumento de 
MHClla e MHC Ild (CAIOZZO et al., 1998). Os diferentes tipos de grupos musculares adaptam-se de maneira diferente ao exercício excêntrico, e assim, lesões ao longo da fibra muscular também podem possuir características diferentes. Diante disso, pode ser questionado se o músculo com características dominantes Tipo I (sóleo) e outro com características Tipo II, apresentarão as mesmas características de lesão da fibra muscular diante de um processo de imobilização.

As alterações observadas com a imobilização são dependentes dos fatores como tempo e posição de imobilização (encurtada ou alongada). Segundo Pattullo et al. (1992) e Goldspink (1999) a imobilização em posição alongada de um músculo composto predominantemente por fibras de contração rápida, determina um transito da MHC mais rápida para mais lenta. No entanto, Mattiello-Sverzut et al. (2006) observaram que o músculo sóleo imobilizado em encurtamento aumenta a expressão de fibras tipo II e reduz a quantidade de fibras tipo I. Estes achados corroboram com o estudo de Heslinga, Kronnie e Huijing (1995), que mostraram maior vulnerabilidade das fibras tipo I a atrofia quando comparados às fibras do tipo II, fato que pode ser explicado por suas diferenças metabólicas durante a fase de imobilização. Essa diminuição da atividade contrátil do músculo contribui para redução da mecanotransdução, o que pode gerar adaptações não apenas no tecido contrátil, mas também no tecido conjuntivo intra e extracelular (KOVANEN, 2002; COUTINHO et al., 2006). 
No processo de reabilitação, para conseguir reverter as alterações resultantes da imobilização é necessário estímulos externos adequados, como a mobilização precoce (HWANG, et al., 2006).

Essas alterações na estrutura músculo esquelético determinadas pelo desuso, são amplamente estudadas e descritas na literatura (BENEDINI-ELIAS et al., 2013; MOURA-JUCÁ et al., submetido; CORNACHIONE et al., 2013; CAÇÃOBENEDINI et al.,2013) e nesse sentido, experimentos utilizando animais em fase de desenvolvimento, são de fundamental importância, pois permite o entendimento dos aspectos celulares e moleculares das respostas musculares à hipoatividade, e posterior reabilitação por meio de técnicas de remobilização como alongamento intermitente, mimetizando situações complexas da clínica de reabilitação (MERCIER et al.,1999).

\subsection{Efeitos do alongamento no músculo esquelético}

O alongamento é definido como uma manobra que afasta a origem da inserção de um determinado músculo ou grupo muscular, e assim, alonga as fibras e aumenta a amplitude de movimento das articulações (SHRIER , 1999). Essa técnica é freqüentemente utilizada na reabilitação do sistema músculo esquelético, de adultos e crianças, com os objetivos de restabelecer a amplitude de movimento, minimizar os efeitos deletérios da imobilização e auxiliar no retorno ao movimento funcional do segmento (KISNER; COLBY 1998; WELDON e HILL, 2003).

Estudos relatam como benefícios deste procedimento, o crescimento 
muscular (LOUGHNA, BROWNSON, 1996), a adição de sarcômeros em série (GOMES et al, 2004), o aumento da amplitude de movimento articular (GAJDOSIK et al, 2007), a melhora na organização das fibras de colágeno (COUTINHO et al, 2006). No entanto, alterações significativas relacionadas ao processo de tumefação (GOMES et al., 2007) e alta reatividade celular também foram observadas, caracterizando processos de degeneração e/ou regeneração desencadeados pelo alongamento (MATTIELLO-SVERZUT et al., 2006).

Em estudo realizado por Okita et al., (2001), o alongamento mantido por trinta minutos, aplicado seis vezes por semana por três semanas consecutivas, foi capaz de induzir o aumento do diâmetro das fibras tipo I em músculos sóleo previamente imobilizados. Concordantemente Coutinho et al (2004), mostraram que sessões de quanrenta minutos de alongamento, aplicados ao músculo sóleo sadio, três vezes por semana, aumentaram o número de sarcômeros em série e a área de secção transversa.

No estudo de Benedini-Elias (2009), o efeito do alongamento em ratas no período de desenvolvimento foi demonstrado por alterações histopatológicas no músculo sóleo. Ainda segundo Oustanina et al, (2004) o músculo sóleo apresenta quantidades expressivas de núcleo centralizado, o que identifica miofibras em regeneração derivadas de células satélites.

Alguns estudos avaliaram as alterações citoarquiteturais do músculo esquelético submetidos à períodos de imobilização em encurtamento (COUTINHO et al, 2006; MATTIELLO-SVERZUT et al, 2006). Entretanto, são escassos estudos sobre essas alterações no tecido músculo esquelético em desenvolvimento, e sua 
relação com estruturas envolvendo colágeno tipo I, III, IV, e filamentos intermediários como a desmina e vimentina. 
OBJETIVOS 


\section{OBJETIVOS}

\subsection{Gerais}

O objetivo deste estudo foi analisar e comparar o efeito do alongamento intermitente aplicado durante 3 dias em animais recém-desmamados submetidos ou não à imobilização do membro posterior direito em flexão plantar. Variáveis relacionadas ao processo de regeneração e adaptação do músculo sóleo foram qualificados e quantificados.

\subsection{Específicos}

Analisar e comparar as respostas adaptativas dos músculos sóleo frente:

- Morfologia convencional;

- Expressão dos colágenos tipos I, III e IV;

- Expressão de filamentos intermediários de desmina e vimentina;

- Expressão de distrofina do costâmero;

- Expressão de CD68 para macrófagos 
MATERIAIS E MÉTODOS 


\section{MATERIAS E MÉTODOS}

\subsection{Animais}

Foram utilizadas 20 ratas da raça Wistar (Rattus norvegicus albinus) fornecidas pelo Biotério Central da Prefeitura do Campus de Ribeirão Preto - USP com 21 dias de idade, que corresponde à fase de desmame e de início dos protocolos propostos neste trabalho. As ratas foram mantidas em grupos de 2 animais, dentro de gaiolas plásticas $(41 \mathrm{~cm} \times 34 \mathrm{~cm} \times 16 \mathrm{~cm})$ com livre acesso à alimentação peletizada e água. Todos os procedimentos para higienização e boa adaptação dos animais nas gaiolas foram realizados. Este estudo foi aprovado pelo Comitê de Ética em Experimentação Animal - CETEA (processo no 043/2007). Os animais foram divididos em 5 grupos: Grupo Controle Inicial(GCIn21- Animais com 21 dias), Grupo Imobilizado (GI- Animais de 21 dias que foram imobilizados por 7 dias), Grupo Imobilizado e Alongado (GIA- Animais de 21 dias que foram imobilizados por 7 e reabilitados pelo alongamento durante 3 dias) e Grupo Alongado (GA- Animais de 21 dias não imobilizados por 7 dias e posteriormente alongamentos durante 3 dias), Grupo Controle Final (GCFn30 Animais com 30 dias). Após o período de intervenção os animais foram eutanaziados com excesso de anestésicos, injeção intraperitonial com excesso de thiopental de sódio (Thiopentax, Cristália, Itapira, São Paulo, Brasil). 


\subsection{Grupos experimentais}

Os animais foram divididos em grupos de acordo com a Tabela 1.

Tabela 1. Divisão dos grupos experiemntais

\begin{tabular}{ccc}
\hline Grupos & $\begin{array}{c}\text { Número } \\
\text { animais }\end{array}$ & \multicolumn{1}{c}{ Procedimentos experimentais } \\
\hline $\begin{array}{c}\text { Controle Inicial } \\
\text { (GCIn 21) }\end{array}$ & 4 & Animais de 21 dias - sacrificados com 21 \\
\hline $\begin{array}{c}\text { Controle } \\
\text { (GCFn 30) }\end{array}$ & 4 & Animais de 21 dias $+7+2-$ sacrificados com 30 dias \\
\hline $\begin{array}{c}\text { Imobilizado } \\
\text { (GI) }\end{array}$ & 4 & $\begin{array}{l}\text { Animais de 21 dias, imobilizados por 7 dias - sacrificados } \\
\text { com 28 dias }\end{array}$ \\
\hline $\begin{array}{c}\text { Imobilizado e } \\
\text { Alongado } 3 \text { dias } \\
\text { (GIA) }\end{array}$ & 4 & $\begin{array}{l}\text { Animais de 21 dias, imobilizados por 7 e alongados por } 3 \\
\text { (consecutivos) - sacrificados com } 30 \text { dias }\end{array}$ \\
\hline $\begin{array}{c}\text { Alongado } 3 \text { dias } \\
\text { (GA) }\end{array}$ & 4 & $\begin{array}{l}\text { Animais de 21 dias + livre por 7 dias + alongados por 3 } 3 \\
\text { dias }- \text { sacrifica com } 30 \text { dias }\end{array}$ \\
\hline Total & 20 & \\
\hline
\end{tabular}

\subsection{Procedimentos Experimentais}

\subsubsection{Técnica de Imobilização}

Este procedimento teve duração de 10 minutos aproximadamente, não foi invasivo e nem doloroso, mas para proteger quem o executou e facilitar 0 manuseio dos animais foi necessário anestesiá-los previamente com Hidrato de Cloral $4 \%$ intraperitoneal, sendo que metade da dose indicada foi utilizada 
$(0,5 \mathrm{ml} / 100 \mathrm{~g})$. Após a anestesia, foi realizado o encurtamento do músculo sóleo através da imobilização da articulação tíbio-társica direita em flexão plantar máxima, com auxílio de uma fita adesiva (WILLIAMS, 1988) (Figura 4).

O modelo de imobilização do membro posterior dos animais utilizados seguiu o modelo proposto por Benedini-Elias et al (2009). A pata direita foi imobilizada através de um modelo de imobilização composto por duas partes: parte superior, similar a uma camiseta de cotton, que permitiu o animal movimentar livremente a cabeça e os membros superiores e, uma parte inferior, dividida em anterior e posterior, composta por uma malha de aço que teve suas bordas envolvidas com fita adesiva para prevenir lesões no corpo do animal. Além disso, no compartimento anterior foi colocada uma "almofada" de algodão para proteger a região anterior do membro. Em seguida, a parte inferior foi unida à parte superior através de grampos. Após este procedimento, a camiseta foi vestida no animal e o membro posterior direito imobilizado através da união das partes anterior e posterior, fixadas com fita crepe (Figura $5 \mathrm{~A}$ e B).

Os animais permaneceram imobilizados por 7 dias consecutivos e separados em número de 2 em gaiolas plásticas $(41 \mathrm{~cm} \times 34 \mathrm{~cm} \times 16 \mathrm{~cm}) \mathrm{com}$ livre acesso a água e ração.

A imobilização não impediu a alimentação e locomoção dos animais dentro da gaiola. No assoalho da gaiola, foi colocada serragem para higienização que será trocada diariamente. 


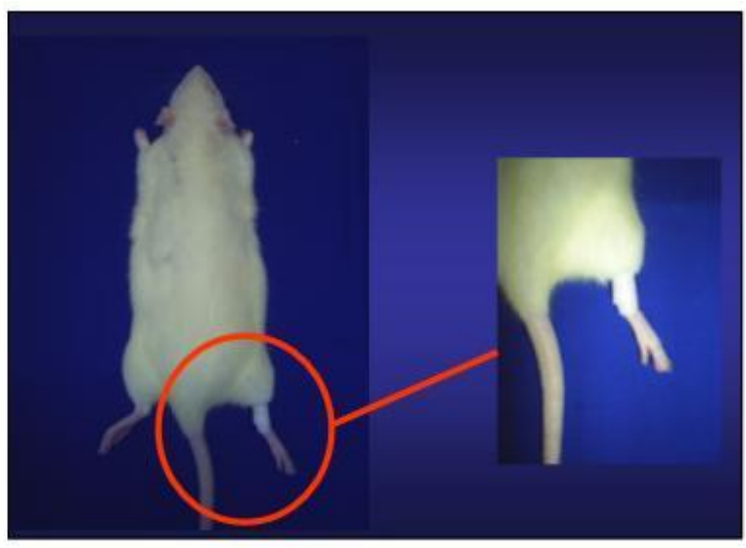

Figura 4. Imobilização da articulação

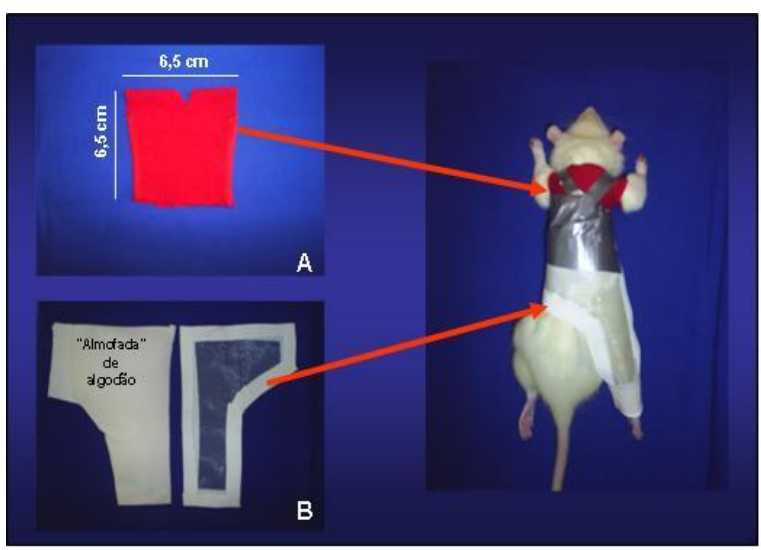

Figura 5 A e B: Modelo de imobilização proposto por BENEDINI-ELIAS et al., (2009). A: Parte superior, similar a uma camiseta de cotton. B: Parte inferior, dividida em anterior e posterior.

\subsubsection{Técnica de alongamento manual passivo}

A técnica de alongamento manual passivo do membro estudado foi realizada com a articulação do joelho em extensão completa. Uma força manual (não quantificada), aplicada na porção plantar da pata posterior direita, produzia o movimento de dorsiflexão da articulação do tornozelo, gerando o alongamento passivo do músculo gastrocnêmio e sóleo das patas, respeitando o limite articular (Figura 6).

Tempo para a realização deste procedimento: - 30s alongamento/30s descanso/10x em um único período do dia (manhã). 


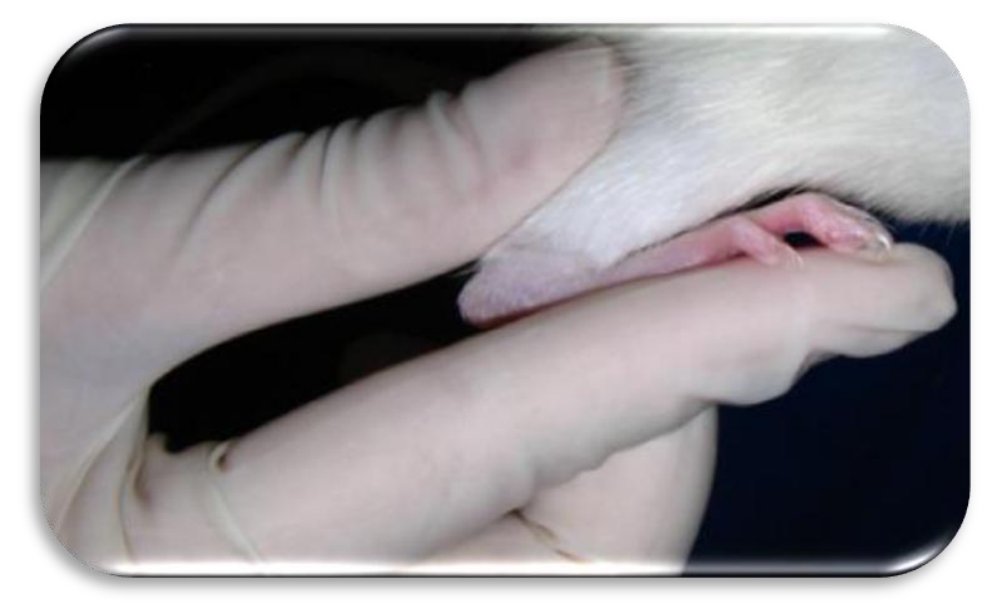

Figura 6. Alongamento manual passivo intermitente

\subsubsection{Obtenção dos Músculos}

O músculo sóleo foi retirado imediatamente após a realização dos protocolos descritos.

Para dissecação do músculo, os animais foram pesados e eutanaziados com excesso de anestésico, injeção intraperitonial com excesso de thiopental de sodio (Thiopentax, Cristália, Itapira, São Paulo, Brasil). Foi realizada uma incisão distal na tíbia do membro posterior direito, próxima à articulação do tornozelo, de forma a expor o músculo sóleo para dissecção e retirada do fragmento. Estes foram envolvidos em talco e submetidos ao congelamento em nitrogênio liquido. $A$ estocagem foi feita em um freezer a $-80^{\circ} \mathrm{C}$ até o processamento do material.

\subsubsection{Processamento Histológico}

Os músculos foram seccionados transversalmente em Criótomo Leica CM 1850 UV a temperatura de $-25^{\circ} \mathrm{C}$. Foram obtidos cortes com $5 \mu \mathrm{m}$ colhidos em 
lâminas $26 \times 76 \mathrm{~mm}$. O processamento contou com a aplicação de reações de coloração: Hematoxilina-Eosina (H.E) e coloração especial (Picro-Sirius), desenvolvido no Laboratório de Neuropatologia do Departamento de Patologia da FMRP-USP, conforme a rotina de processamento de músculo esquelético deste laboratório.

\subsection{Processamentos imunoistoquímicos para colágeno Tipos I, III e IV, vimentina , desmina e imunofluorescência para distrofina e CD 68.}

Os músculos foram seccionados transversalmente em Criótomo Leica CM 1850 UV a temperatura de $-25^{\circ} \mathrm{C}$. Foram obtidos cortes com $5 \mu \mathrm{m}$ colhidos em lâminas 26x76mm para coloração especial picro-sirius (Dapson et al, 2011). Para a técnica imunoistoquímica foram utilizados os anticorpos anti-rat collagen type I, type III e type IV (Sigma), mouse anti- human desmin (DAKO) e mouse anti-human vimentin (DAKO). Estas técnicas foram realizadas no Laboratório de Neuropatologia do Departamento de Patologia da FMRP-USP, conforme a rotina de processamento de músculo esquelético deste laboratório. As lâminas foram fixadas em acetona gelada por 10 minutos, lavadas com PBS e incubadas em solução de 3\% H2O2 por 15 minutos para bloqueio da peroxidase endógena. Foram novamente lavadas e em seguida realizado o bloqueio de ligações inespecíficas com Soro Normal de Cavalo (ABC KIT Vectastain- PK6200- Vector) por 60 minutos. Os excessos de líquido foram removidos e as amostras foram incubadas separadamente com os anticorpos primários monoclonal mouse anti-rat 
collagen type I (1:18000), collagen type III (Sigma) (1:36000), anti-rat collagen type IV (Sigma) (1:800), mouse anti-human desmin (DAKO) (1:100), mouse anti-human vimentin (DAKO) $(1: 100)$ à $4^{\circ} \mathrm{C}$ overnight. Foi feito um controle negativo (blanc), pelo não gotejamento do anticorpo primário no tecido. No dia seguinte, as lâminas foram lavadas em Tampão Tris Salino com Tween 20 (TBST) 3 vezes e incubadas com o anticorpo secundário ABC KIT Vectastain- PK6200- Vector durante 30 minutos. Logo após foram lavadas 3 vezes e incubadas com o Avidina e Biotina (ABC KIT Vectastain- PK6200- Vector) por 30 minutos e em seguida ocorreu nova lavagem com TBST e TRIS-HCl para incubação do cromógeno DAB (diaminobenzidina), durante 5 minutos. Foi realizada lavagem em água corrente, contracoração com Hematoxilina por 10 segundos, desidratação e a diafanização e por fim a montagem em Permount (Fisher).

A técnica de imunofluorescência foi realizada com dupla marcação para distrofina e CD68, com aplicação de 2 anticorpos primários rabbit polyclonal antiDISTROFIN, diluição 1:100 (Abcam) e mouse monoclonal anti-CD68, diluição 1:200 (Abcam). As lâminas foram lavadas em tampão tris salino (TBS), fixadas em Xpress molecular fixative durante 4 minutos, lavadas novamente duas vezes com o mesmo tampão. Os excessos de líquido foram removidos e as amostras foram incubadas com seus respectivos anticorpos primários a $37^{\circ} \mathrm{C}$ por 2 horas. $\mathrm{Na}$ sequência os cortes foram lavados 3 vezes em PBS em um intervalo de 5 minutos e posteriormente aplicado 2 anticorpos secundários (molecular probes fluorescent goat anti-rabbit green 488 e goat anti-mouse red 568), por $45 \mathrm{~min}$. As lâminas foram lavadas 2 vezes com TBS e montadas em Prolong Gold Antifade. 
Os resíduos de diaminobenzidina (DAB) foram tratados com soluções-estoque de permanganato de potássio $0,2 \mathrm{M}(31,6 \mathrm{~g} / \mathrm{litro})$ e de ácido sulfúrico $2 \mathrm{M}(112 \mathrm{ml}$ ácido concentrado/litro). Posteriormente foi acrescido ácido ascórbico. A solução foi neutralizada com carbonato ou bicarbonato de sódio até pH 7. Para finalizar, a solução foi descartada na pia com água.

\subsection{Estudo Morfológico}

As análises qualitativas dos cortes histológicos transversais foram realizadas em Microscópio de Luz Leica DM 2500 (Leica Microsystems, Frankfurt, Alemanha). Aspectos morfológicos genéricos do tecido muscular foram avaliados pela coloração H.E.

\subsection{Análise semi-quantitativa para os colágenos dos tipos I, III e IV e Picro Sírius}

Esta análise foi realizada no Microscópio de Luz citado anteriormente, por três examinadores independentes, para todos os grupos experimentais aqui estudados. Na análise, foi utilizada a classificação descrita por Kurose et al. (2006) levando em conta a reatividade dos mesmos: negativo (-); ligeiramente positivo ( $)$; fracamente positivo $(+)$; moderadamente positivo $(++)$; fortemente positivo $(+++)$.

\subsection{Relação de imunorreatividade para desmina e vimentina entre os grupo.}

Através da imunomarcação para desmina pelo anticorpo mouse antihuman desmin e imunomarcação para vimentina pelo anticorpo mouse anti-human 
vimentin, três campos aleatórios das lâminas do músculo sóleo de cada animal foram colhidos. Foi selecionado um campo com uma célula marcada com desmina e a relação da quantidade de pixels para todas as outras amostras foi a partir desta, para não haver divergências no resultado. Para a marcação de vimentina foi realizado o mesmo procedimento. As imagens formam processadas pelo software Leica LAS V3.8 A partir destes dados, foi estabelecida a análise estatística entre os grupos (Figura 7 e 8 )

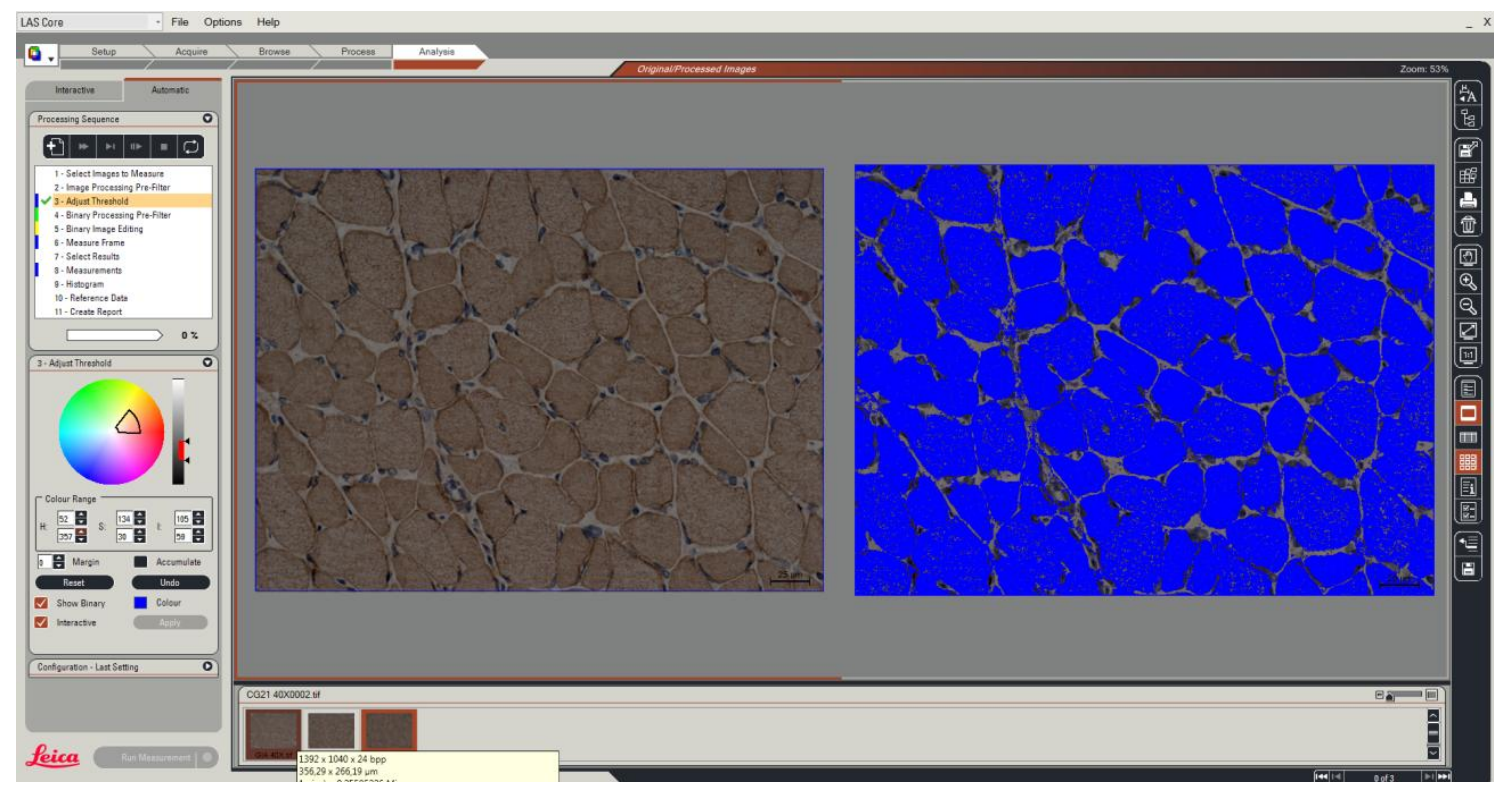

Figura 7. Software Leica LAS V3.8 - Análise quantitativa dos filamentos intermedários 


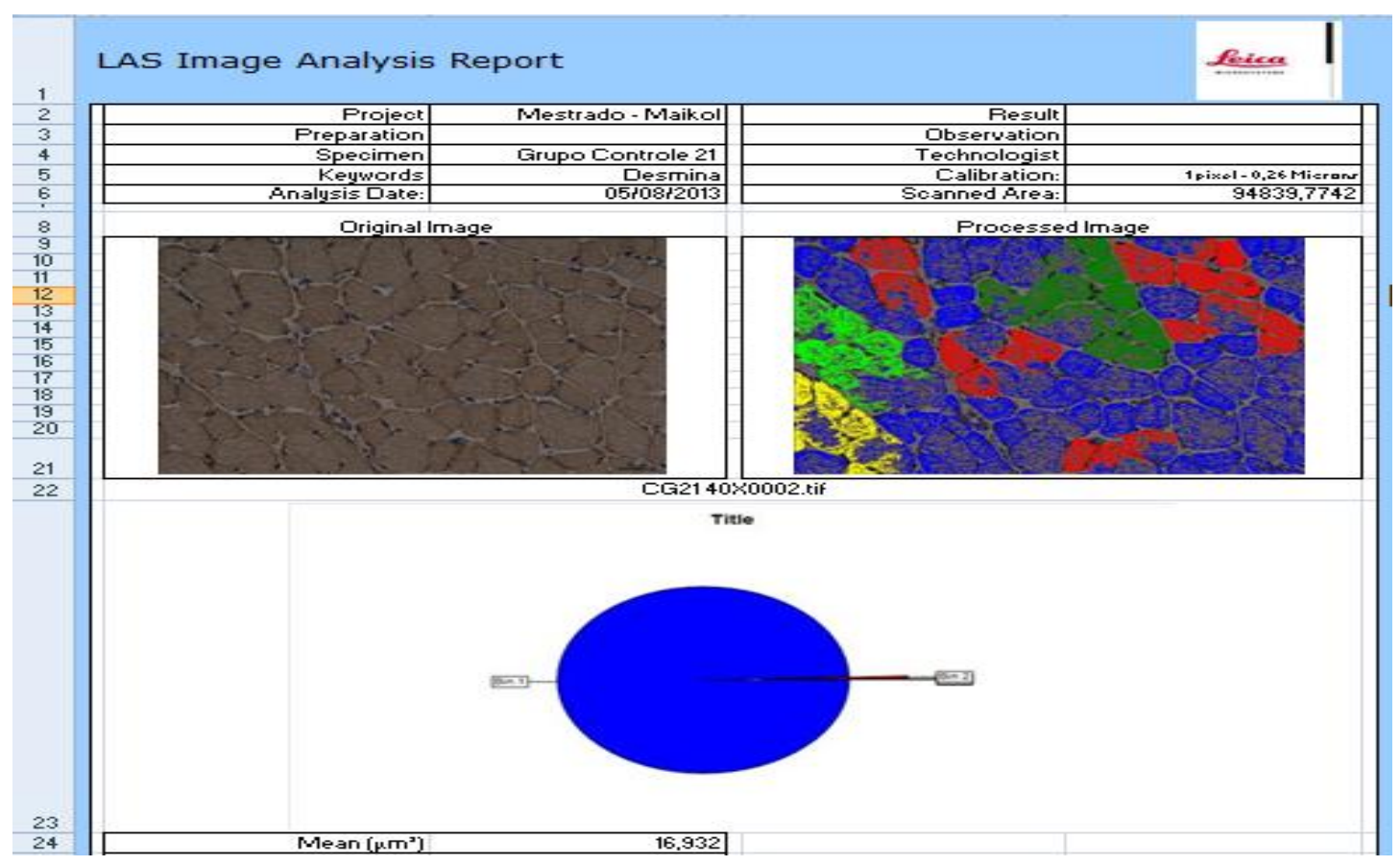

Figura 8. Software Leica LAS V3.8 - Análise gráfica dos filamentos intermediários

\subsection{Densidade de macrófagos e corpos de inclusão}

Com a utilização da imunofluorescência pelo anticorpo mouse anti-rat CD68, a partir de imagens colhidas em três campos aleatórios das lâminas do músculo sóleo dos animais dos grupos aqui estudados, foram contados os macrófagos e os corpos de inclusão através do segmento interativo do software Leica LAS V3.8 (Figura 8). 


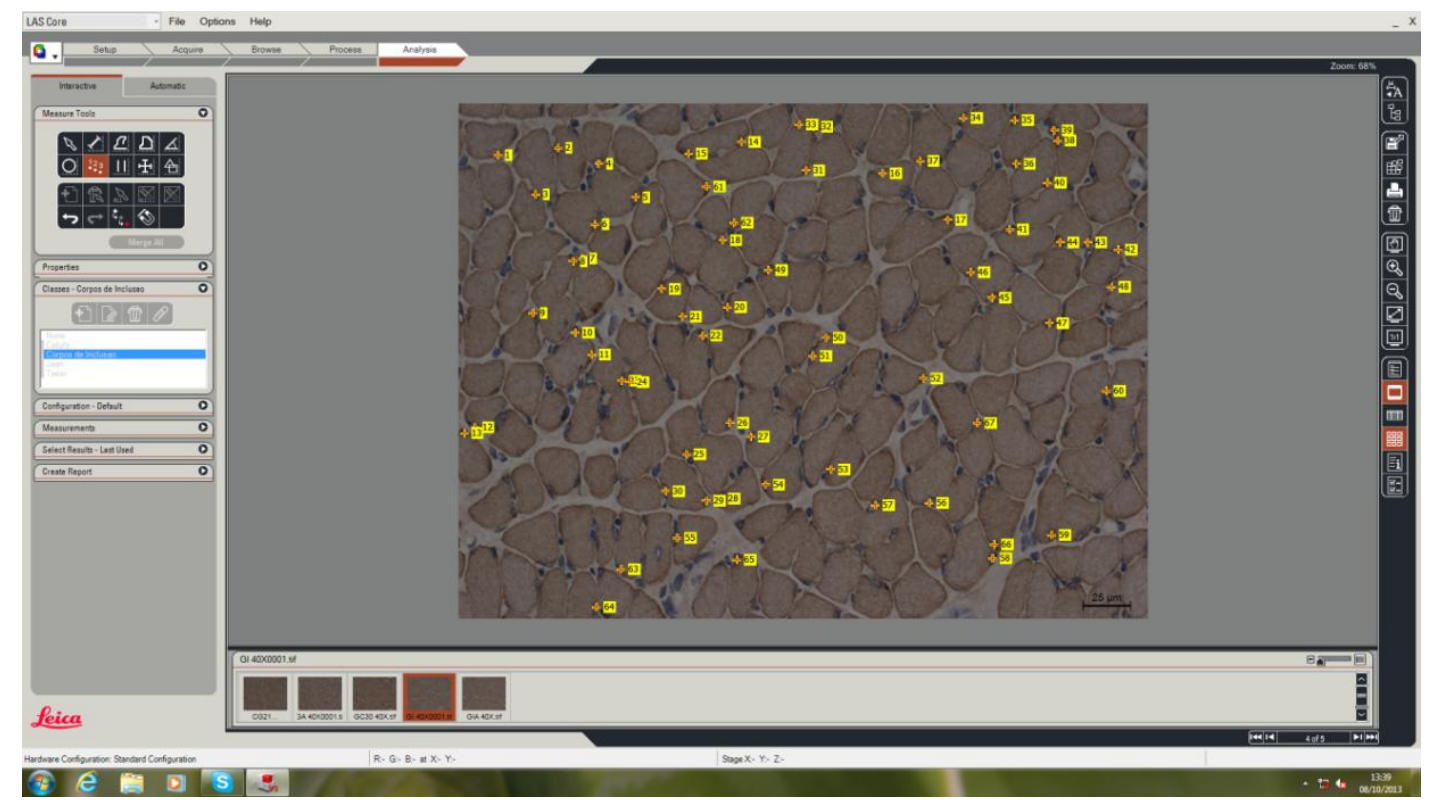

Figura 9. Software Leica LAS V3.8 - Contagem corpos de Inclusão

\subsection{Análise estatística}

Para comparação dos dados obtidos nos diferentes grupos, inicialmente realizou-se uma análise exploratória dos dados, com o objetivo básico de sumarizar as informações, organizá-las e descrevê-las de duas maneiras: por meio de tabelas com medidas descritivas e de gráficos.

Para atingir o objetivo propostos utilizou-se o teste de Kruskall Wallis, que é uma técnica não paramétrica utilizada para comparar dois ou mais grupos. Sendo assim, ela não requer suposições quanto a distribuição dos dados. Para as comparações entre os grupos utilizou-se pós teste de Dunn. Os resultados foram obtidos com o auxilio do software R (versão3.0) 
RESULTADOS 
RESULTADOS - 53

\section{RESULTADOS}

\subsection{Análise histopatológica hematoxilina-eosina}

Os principais achados histopatológicos observados nos músculos dos animais foram corpos de inclusão, fragmentação e central core. A Tabela 2 e Figura 10 sumarizam esses dados. Análise estatística indicou que o número de corpos de inclusão dos animais dos Gl e GIA esteve significativamente aumentado em relação ao grupo controle 21 dias e, GIA também apresentou valores superiores em relação ao grupo controle 30 dias (GC21 x GI; GC21 x GIA; GC30 x GIA; $p<0,05)$. Para a fragmentação de fibras, foi observado aumento significativo deste achado nos animais do GIA em relação ao GC21 e GC30 (GC21 x GIA; GC30 x GIA; $p<0,05)$. A anomalia de central core mostrou-se significativamente modificada nos animais dos GI, GIA em relação aos controles 21 e 30 dias e GA (GC21 x GI; GC21 x GIA; GC30 x Gl; GC30 x GIA; GI x GA; GIA x GA; p<0,05).

Tabela 2. Alterações histopatológicas por grupos

\begin{tabular}{|c|c|c|c|c|c|}
\hline Alterações & Grupos & & & & \\
\hline & GC21 & CG30 & $\mathrm{Gl}$ & GIA & GA \\
\hline $\begin{array}{l}\text { Corpos de } \\
\text { Inclusão }\end{array}$ & 0,0 & $4,25( \pm 1.71)$ & $129.75( \pm 4.43)^{*}$ & $106( \pm 2.94)^{* \circ}$ & $16( \pm 2.94)$ \\
\hline Fragmentação & 0,0 & 0,0 & $3.00( \pm 0.82)$ & $4.75( \pm 0.96)^{\star \circ}$ & $2.5( \pm 1.29)$ \\
\hline Central core & 0,0 & 0,0 & $1.75( \pm 0.96) \#^{\star \circ}$ & $2.00( \pm 0.82) \#^{* \circ}$ & 0,0 \\
\hline $\begin{array}{l}\text { Resultados den } \\
\text { teste de Dunn; } \\
\text { grupo imobilizac }\end{array}$ & $\begin{array}{l}\text { nstrados } \\
\text { C21, grup } \\
\text {; GIA, gru }\end{array}$ & $\begin{array}{l}\text { com média e } \\
\text { controle com } \\
\text { o imobilizado }\end{array}$ & $\begin{array}{l}\text { lesvio padrão: Te } \\
21 \text { dias; GC30, gr } \\
\text { alongado; GA, g }\end{array}$ & $\begin{array}{l}\text { te de Kruskall W } \\
\text { po controle com } \\
\text { ıpo alongado }\end{array}$ & $\begin{array}{l}\text { allis - pós } \\
0 \text { dias; GI, }\end{array}$ \\
\hline - sem alteraçõe & & & & & \\
\hline${ }^{*} p<0.05$ compa & ido $\operatorname{com} C$ & $\mathrm{C} 21$ & & & \\
\hline${ }^{\circ} \mathrm{p}<0.05$ compa & ido $\operatorname{com} C$ & C30 & & & \\
\hline$\# p<0.05$ comp & do com & & & & \\
\hline
\end{tabular}



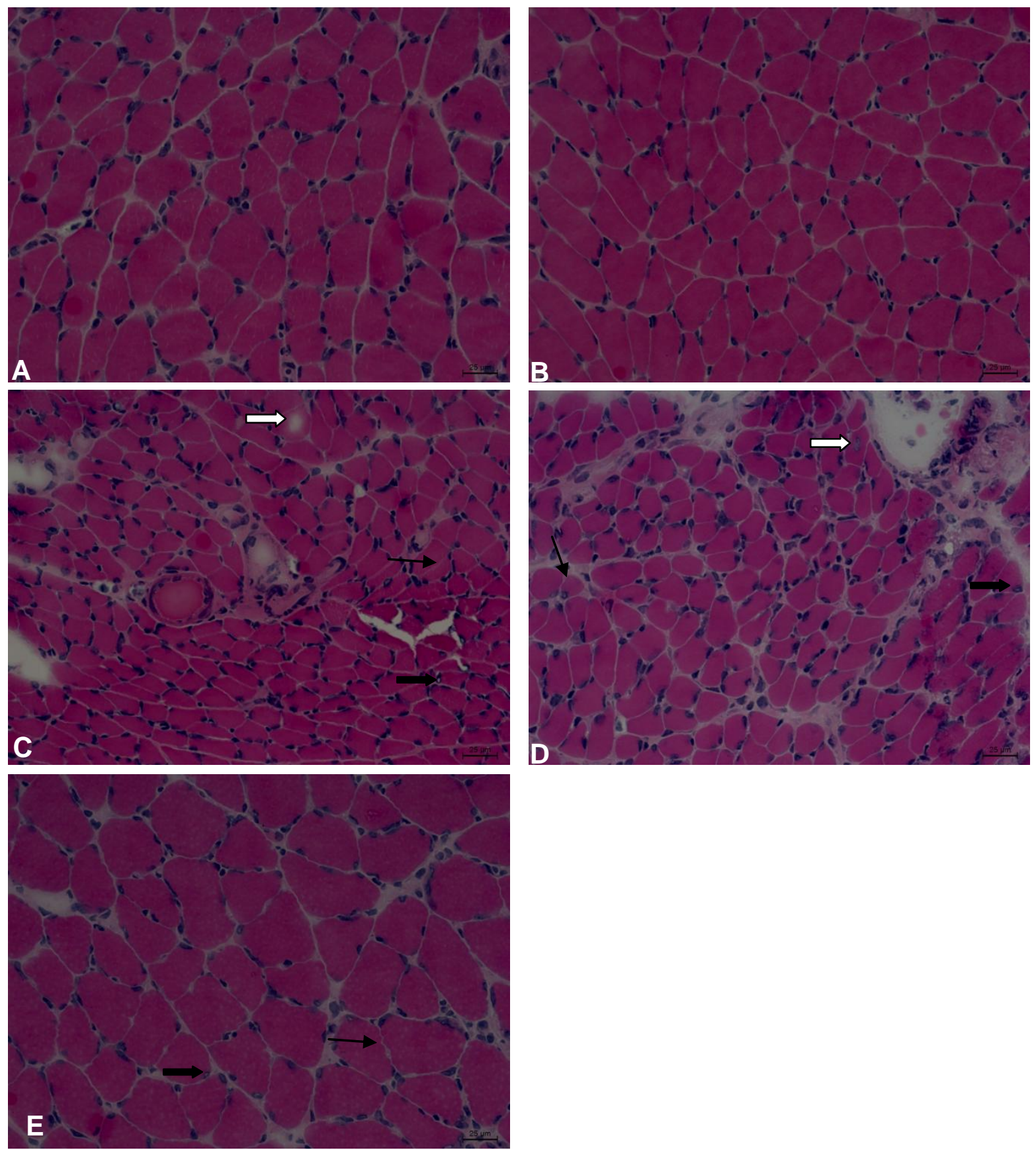

Figura 10. Fotomicrografia do músculo sóleo, corado com HE. ( Barra: 25 $\mu \mathrm{m}$ ) (A) Grupo Controle 21 dias: núcleo centralizado (seta branca); (B) Gupo Controle 30 dias: sem alterações; (C) Grupo Imobilizado: Variação no tamanho das fibras, fragmentção (seta preta fina), lesão tipo "central core" (seta branca), corpos de inclusão (seta preta grossa); (D) Grupo Imobilizado e Alongado: Variação no tamanho das fibras, lesão central core (seta branca), corpos de inclusão (seta preta grossa) (E) Grupo Alongado: Presença de fragmentação (seta preta fina) e corpos de inclusão (seta preta grossa). 


\subsection{ANÁlise DA COLORAÇÃo ESPECIAL - PICRO-SIRIUS, IMUNOISTOQUIMICA PARA COLÁGENO TIPO I, III E IV.}

Análise semiquantitativa da coloração especial por picro-sirius indicou que os fragmentos de músculo sóleo dos grupos controle 21 e 30 dias, GI , GIA e GA apresentaram intensidade de coloração à luz polarizada moderadamente positiva para fortemente positiva $(++/+++)$ (Figura 11). A expressão do colágeno I nos fragmentos de músculo sóleo pela análise semiquantitativa foi classificada como moderadamente positiva (++) para o grupo Gl enquanto os demais grupos apresentaram expressão fracamente positiva (+) (Figura 12). A expressão de colágeno III foi igual para os fragmentos de sóleo de todos os grupos e foi classificada como moderadamente positiva (++) (Figura 13). Para o colágeno IV, a expressão em GC21, GC30 e GA foi classificada como fortemente positiva (+++). Para os músculos do Gl e GIA foi obtida classificação da expressão como levemente positiva (++) (Figura 14). Os resultados estão sumarizados na Tabela 3.

Tabela 3. Análise semiquantitativa dos Colágenos I,III, IV e coloração especial Picro-sírius

\begin{tabular}{cccccc}
\hline & GC(21) & GC(30) & GI & GIA & GA \\
\hline Picro-sírius & $++/+++$ & $++/+++$ & $++/+++$ & $++/+++$ & $++/+++$ \\
\hline Colágeno I & + & + & ++ & + & + \\
\hline Colágeno III & ++ & ++ & ++ & ++ & ++ \\
Colágeno IV & +++ & +++ & ++ & ++ & +++ \\
\hline
\end{tabular}

Legenda: - ausente; \pm ligeiramente presente; + pouca quantidade; ++ quantidade moderada; +++ muita quantidade. 

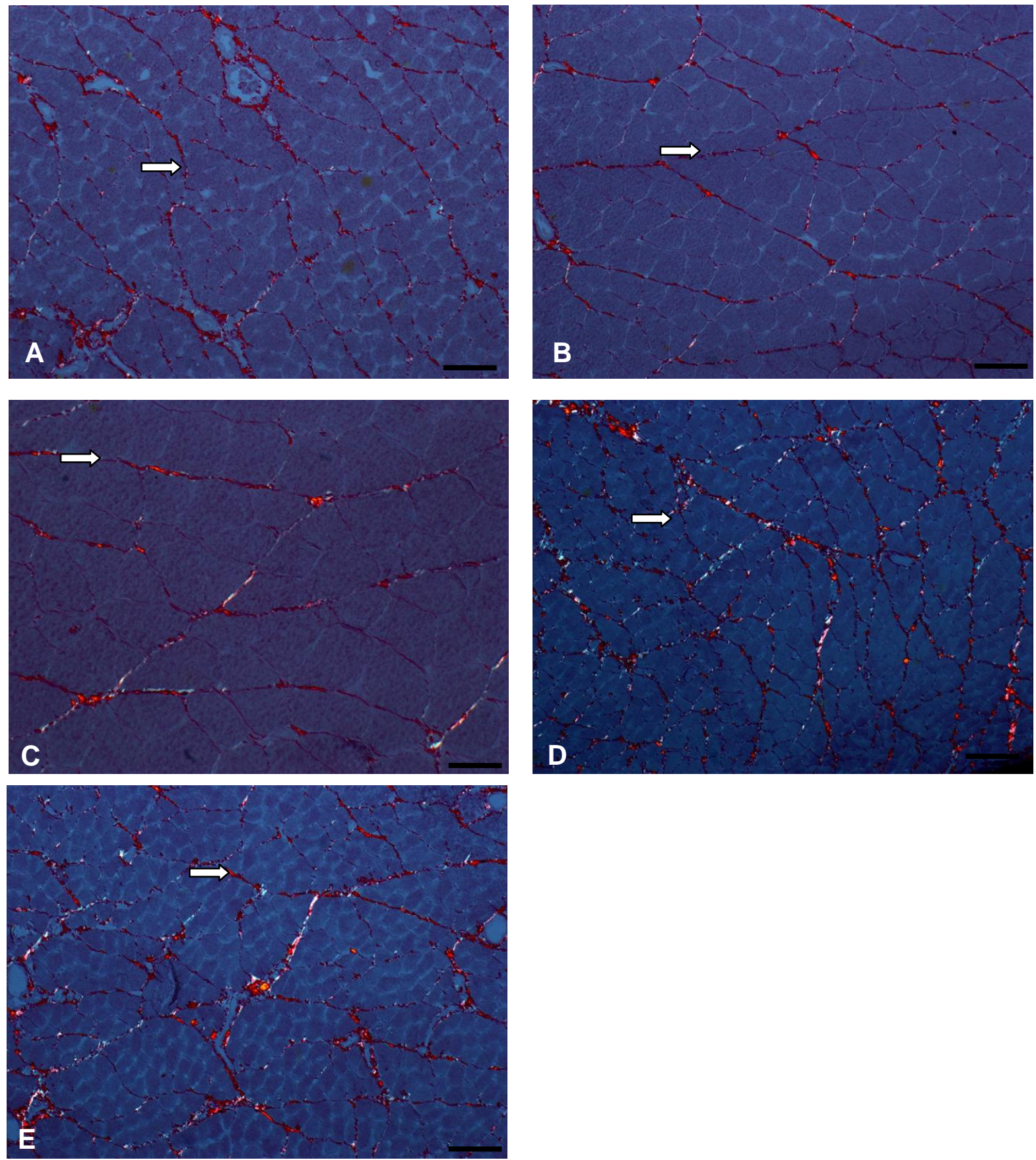

Figura 11. Fotomicrografia do músculo sóleo, picrosirius ( Barra: $25 \mu \mathrm{m}$ )

(A luz polarizada) Grupo Controle 21 dias Marcação moderada - forte (seta branca) (B luz polarizada) Gupo Controle 30 dias: Marcação moderada-forte (seta branca); (C luz polarizada) Grupo Imobilizado: Marcação moderada-forte (seta branca) (D luz polarizada) Grupo Imobilizado e Alongado Marcação moderada-forte (seta branca); (E luz polarizada) Grupo Alongado: Marcação moderada-forte (seta branca) 

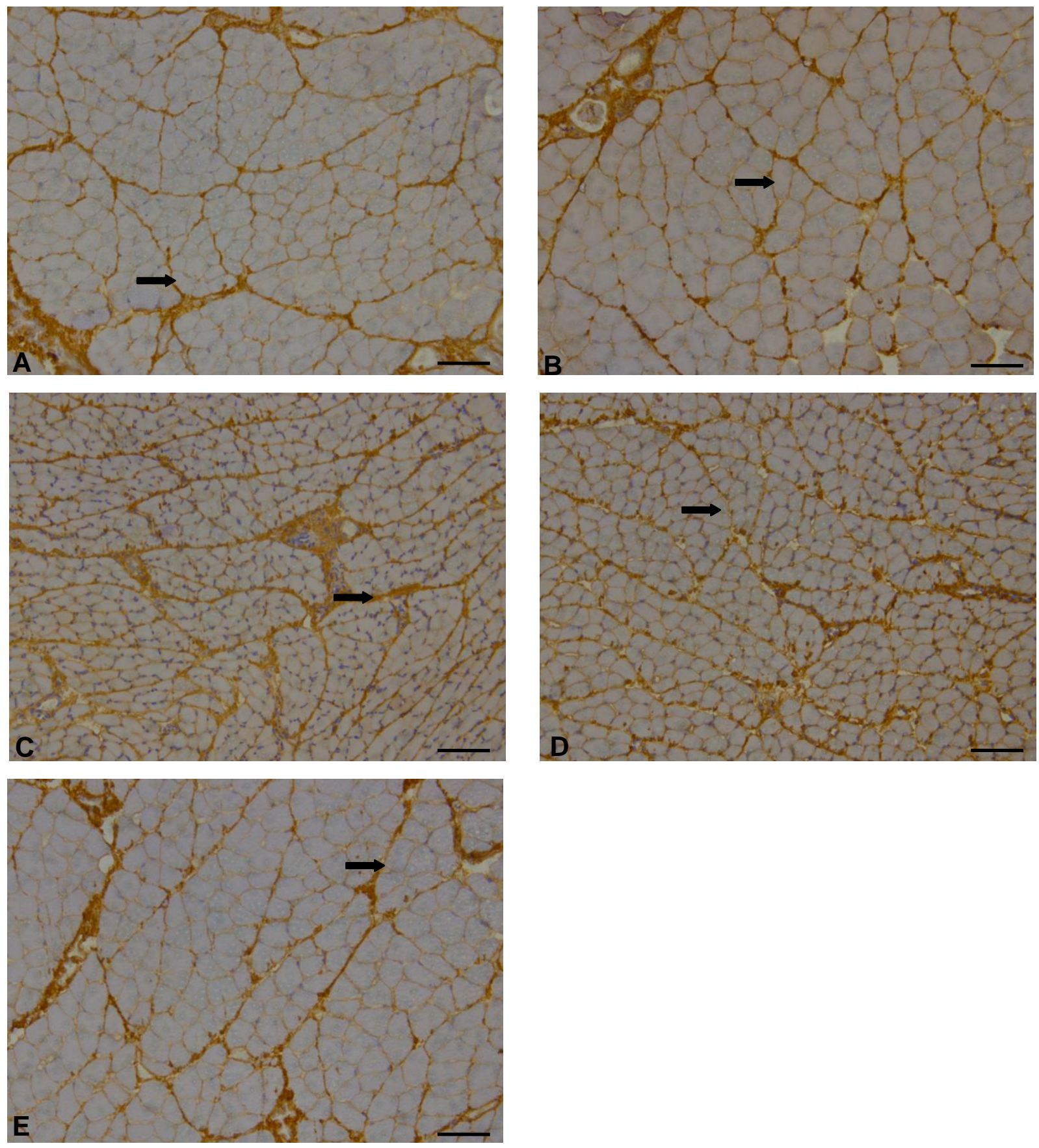

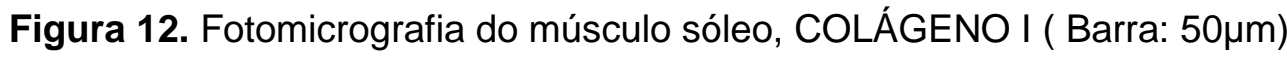

(A) Grupo Controle 21 dias: Pouca marcação(seta preta grossa); (B) Gupo Controle 30 dias: Pouca marcação(seta preta grossa); (C) Grupo Imobilizado: marcação moderada (setas preta grossa) (D) Grupo Imobilizado e Alongado: Pouca marcação(seta preta grossa); (E) Grupo Alongado: marcação moderada (setas preta grossa) 

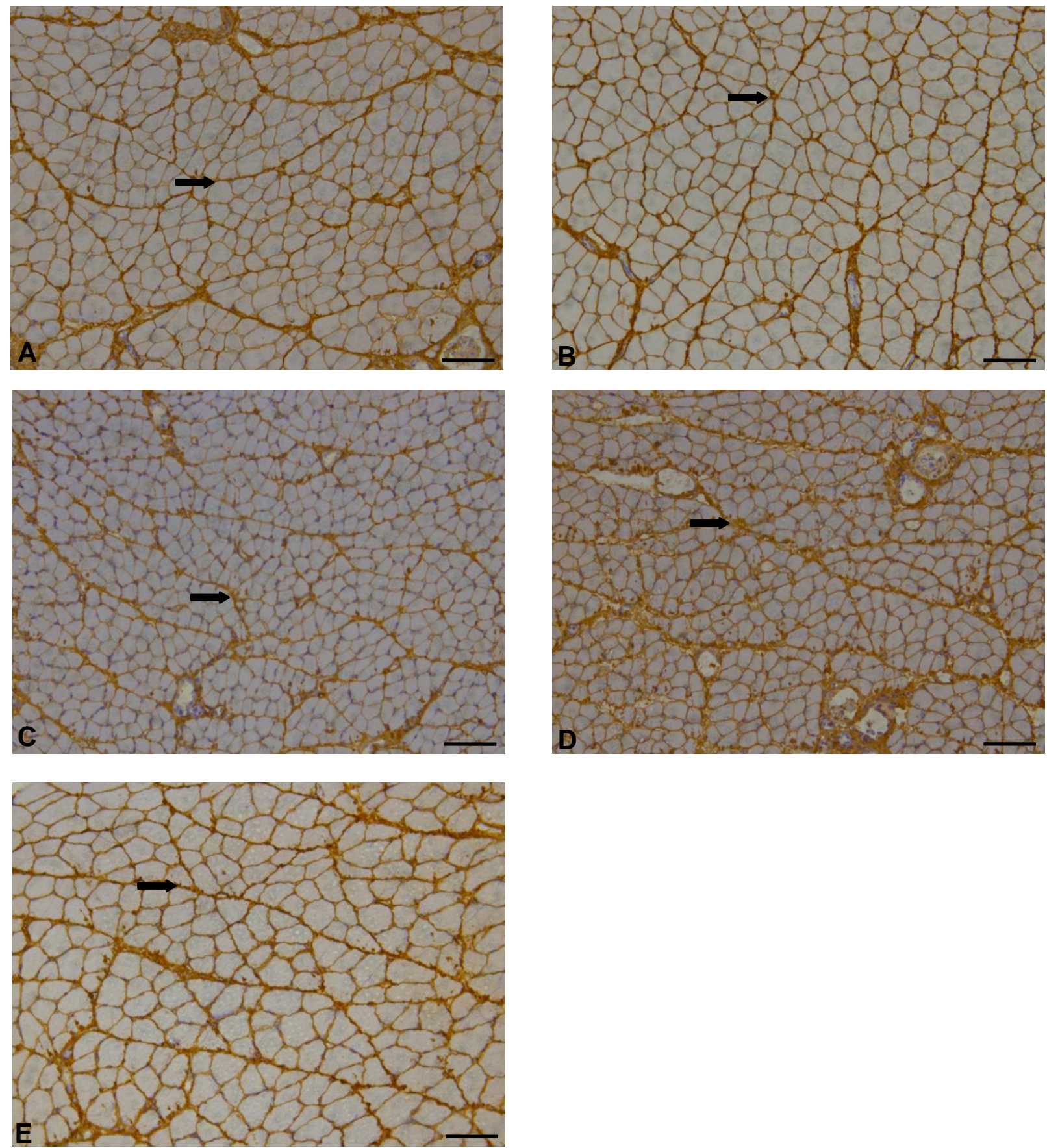

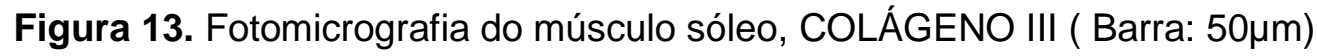

(A) Grupo Controle 21 dias: Marcação moderada (seta preta grossa); (B) Gupo Controle 30 dias: Marcação moderada (seta preta grossa); (C) Grupo Imobilizado: Marcação moderada (seta preta grossa); (D) Grupo Imobilizado e Alongado Marcação moderada (seta preta grossa); (E) Grupo Alongado: Marcação moderada (seta preta grossa) 

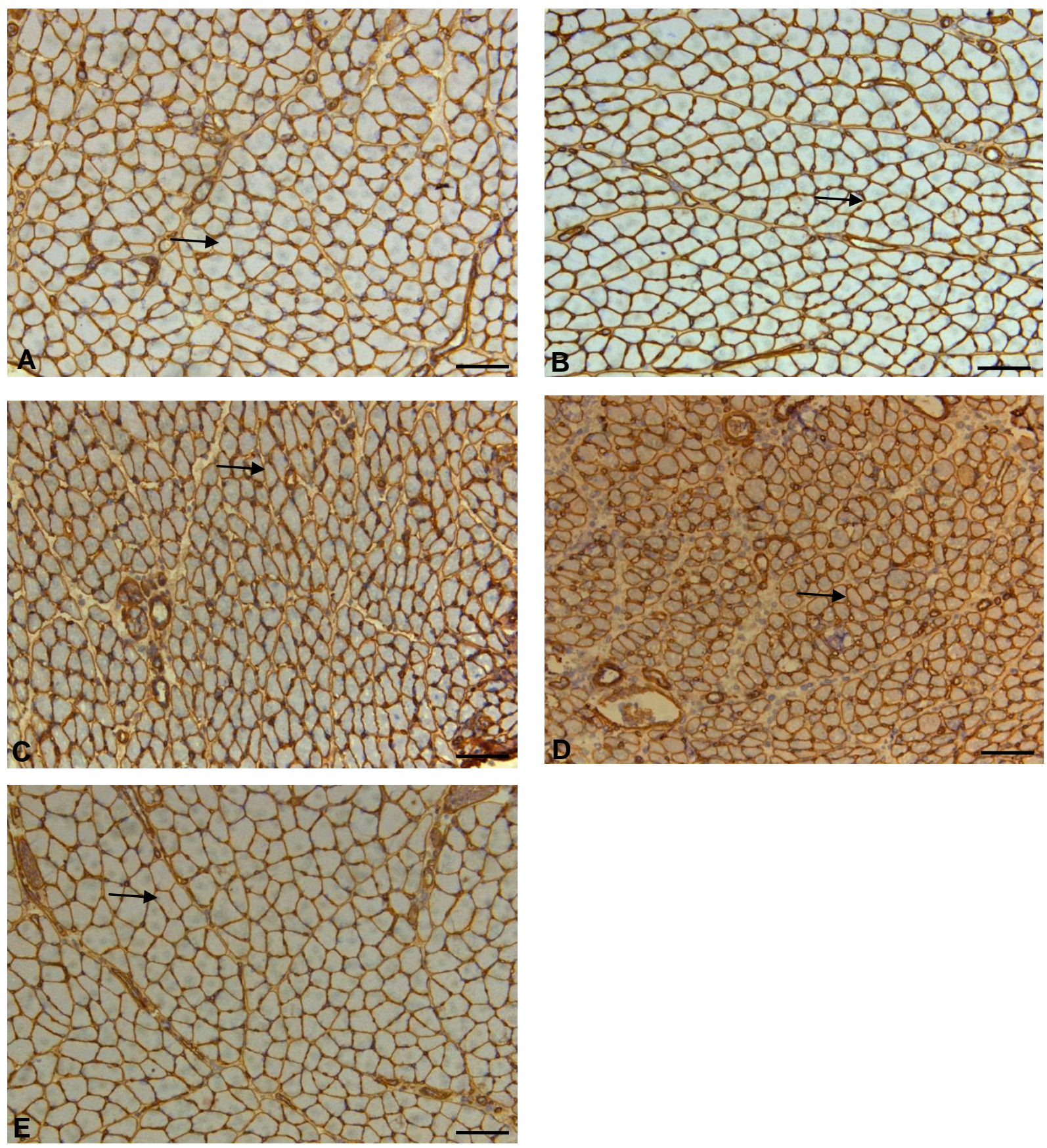

Figura 14. Fotomicrografia do músculo sóleo, COLÁGENO IV ( Barra: 50 $\mu \mathrm{m}$ )

(A) Grupo Controle 21 dias : Marcação forte (seta preta); (B) Gupo Controle 30 dias: Marcação forte (seta preta) (C) Grupo Imobilizado: Marcação moderada (seta preta) (D) Grupo Imobilizado e Alongado Marcação moderada (seta preta) (E) Grupo Alongado: marcação forte (seta preta) 
RESULTADOS - 60

\subsection{Análise da imunoistoquimica para desmina, vimentina e CD68}

Análise da estatística da expressão de desmina indicou aumento na diferença significativa entre os dados obtidos dos GC21 e GC30 em relação ao Gl e do GC30 em relação ao GIA (GC21 x GI; GC30 x GI; GC30 x GIA; p<0,05) (Figura 14). Para vimentina, foi observada aumento na diferença significativa entre os dados obtidos dos GC21 e GC30 em relação ao Gl e do GC21 em relação ao GIA (GC21 x Gl; GC30 x Gl; GC21 x GIA; p<0,05) (Figura 15). A densidade de macrófagos analisada pela expressão de CD68 indicou diferença significativa somente entre os dados obtidos dos GC21 e GC30 em relação ao GIA (GC21 x GIA; GC30 x GIA; p<0,05). Os resultados estão sumarizados na tabela 4.

Tabela 4. Imunorreatividade para desmina e vimentina e densidade de macrófagos (CD68) por grupo

\begin{tabular}{lccccc}
\hline Imunoistoquímica & Grupos & \multicolumn{5}{c}{} \\
\cline { 2 - 6 } & GC21 & CG30 & Gl & GIA & GA \\
Desmina & $16.79( \pm 0.20)$ & $21.33( \pm 0.28)$ & $4.64( \pm 0.13)^{\star \circ}$ & $5.09( \pm 0.04)^{\circ}$ & $9.4( \pm 0.08)$ \\
Vimentina & $7.49( \pm 0.09)$ & $7.26( \pm 0.09)$ & $5.83( \pm 0.03)^{* \circ}$ & $6.14( \pm 0.05)^{\star}$ & $6.26( \pm 0.06)$ \\
CD 68 & 0,0 & 0,0 & $6.75( \pm 1,26)$ & $9.50( \pm 1.29)^{\star \circ}$ & $2.75( \pm 0.96)$ \\
\hline
\end{tabular}

Resultados demonstrados com média e desvio padrão: Teste de Kruskall Wallis pós teste de Dunn; GC21, grupo controle com 21 dias; GC30, grupo controle com 30 dias; GI, grupo imobilizado; GIA, grupo imobilizado e alongado; GA, grupo alongado

- sem alterações

* $p<0.05$ comparado com GC21

- $p<0.05$ comparado com GC30

\# $p<0.05$ comparado com GA 

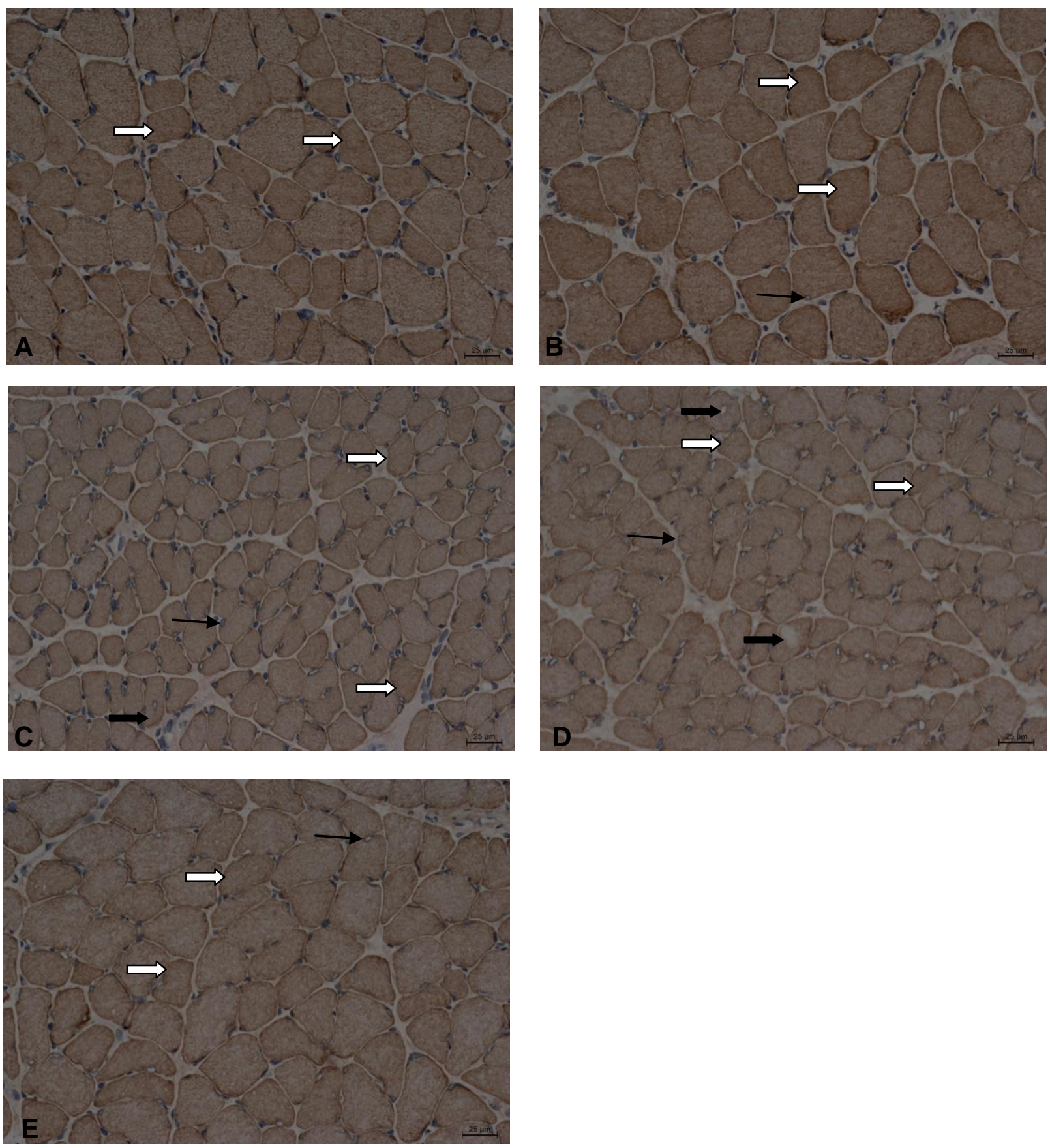

Figura 15. Fotomicrografia do músculo sóleo, DESMINA ( Barra: $25 \mu \mathrm{m}$ )

(A) Grupo Controle 21 dias: Presença de imuno-reatividade (seta branca); (B) Gupo Controle 30 dias: Presença de imuno-reatividade (seta branca);corpos de inclusão (seta preta fina); (C) Grupo Imobilizado: Presença de imuno-reatividade (seta branca);corpos de inclusão (seta preta fina), lesão central core (seta preta grossa) (D) Grupo Imobilizado e Alongado: Presença de imunoreatividade (seta branca);corpos de inclusão (seta preta fina), lesão central core (seta preta grossa) (E) Grupo Alongado: Presença de imuno-reatividade (seta branca);corpos de inclusão (seta preta fina). 

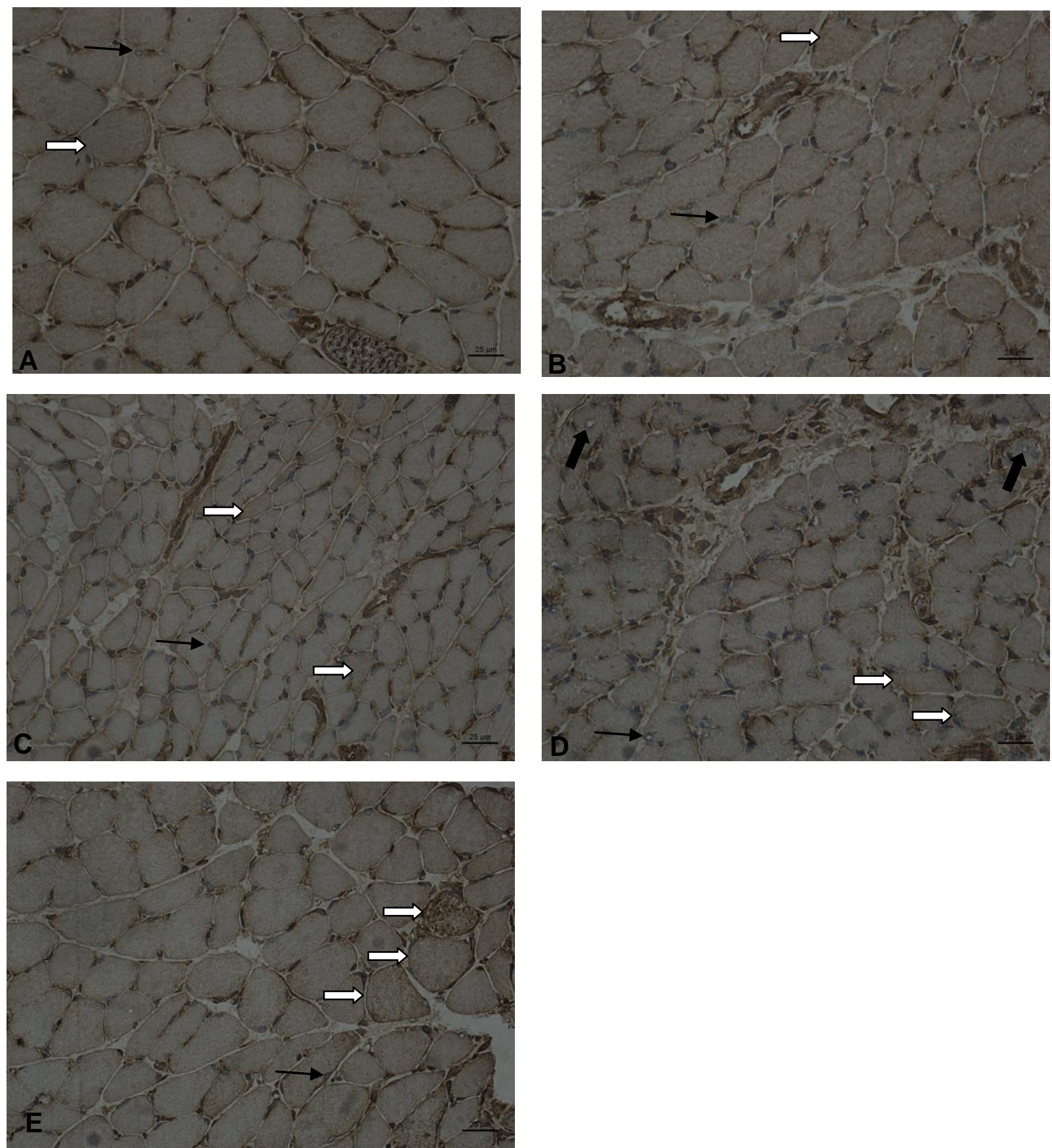

Figura 16. Fotomicrografia do músculo sóleo, VIMENTINA ( Barra: $25 \mu \mathrm{m}$ )

(A) Grupo Controle 21 dias: Presença de imuno-reatividade (seta branca); (B) Gupo Controle 30 dias: Presença de imuno-reatividade (seta branca);corpos de inclusão (seta preta); (C) Grupo Imobilizado: Presença de imuno-reatividade (seta branca);corpos de inclusão (seta preta fina); (D) Grupo Imobilizado e Alongado: Presença de imuno-reatividade (seta branca);corpos de inclusão (seta preta fina), lesão central (seta preta grossa) (E) Grupo Alongado: Presença de imunoreatividade ( seta branca);corpos de inclusão ( seta preta fina). 
A marcação para distrofina no eixo transversal das fibras dos músculos sóleos pode ser vista na Figura 17 (A2,B2, C2, D2 e E2. Os grupos GC 21 e GC30 não apresentaram alterações na fluorescência para distrofina em relação aos grupos GI, GIA e GA, como também ausência de macrófagos tanto intra como extracelular (tabela 4). O procedimento de imobilização e remobilização pelo alongamento manual passivo intermitente por 3 dias provocou alterações para distrofina como descontinuidade, o que sugere ruptura sarcolemal, ondulações sarcolemais e diminuição da espessura na fluorescência para os grupos GI, GIA e $\mathrm{GA}$, com presença de macrófagos na região extracelular nos grupos Gl e GA e macrófagos nas regiões intra e extra celular no grupo GIA (Figura 17 - C2,D2,E2, C4,D4,E4). 
GC 21

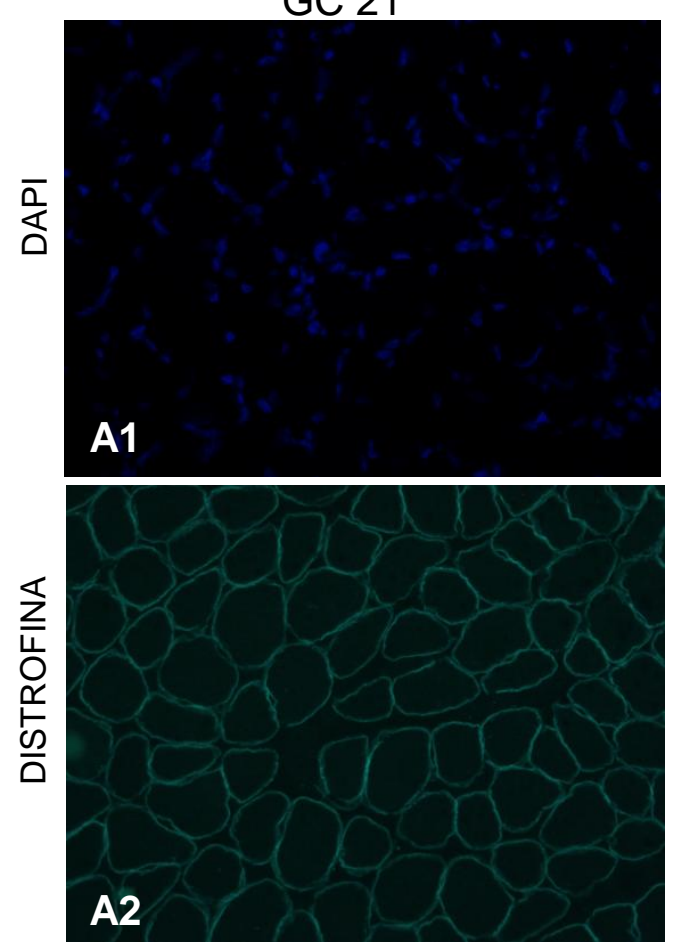

$\infty$

8

A3

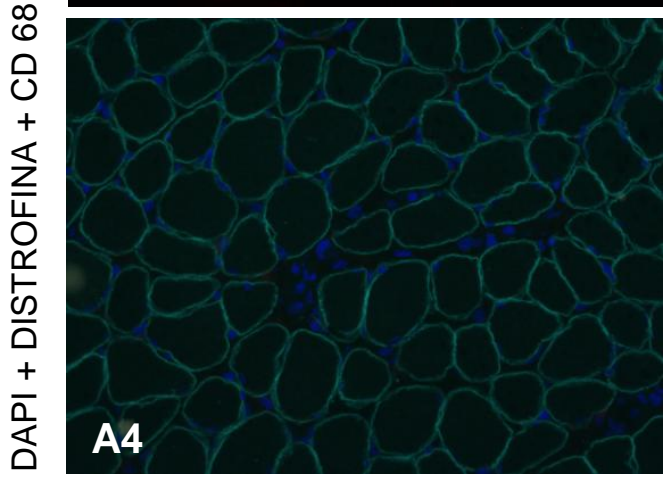

GC 30

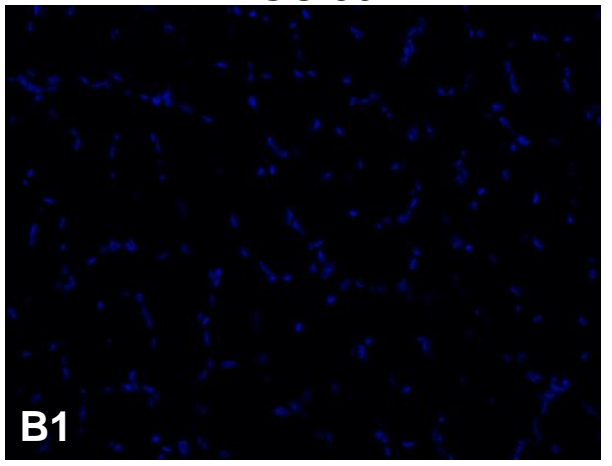

B2

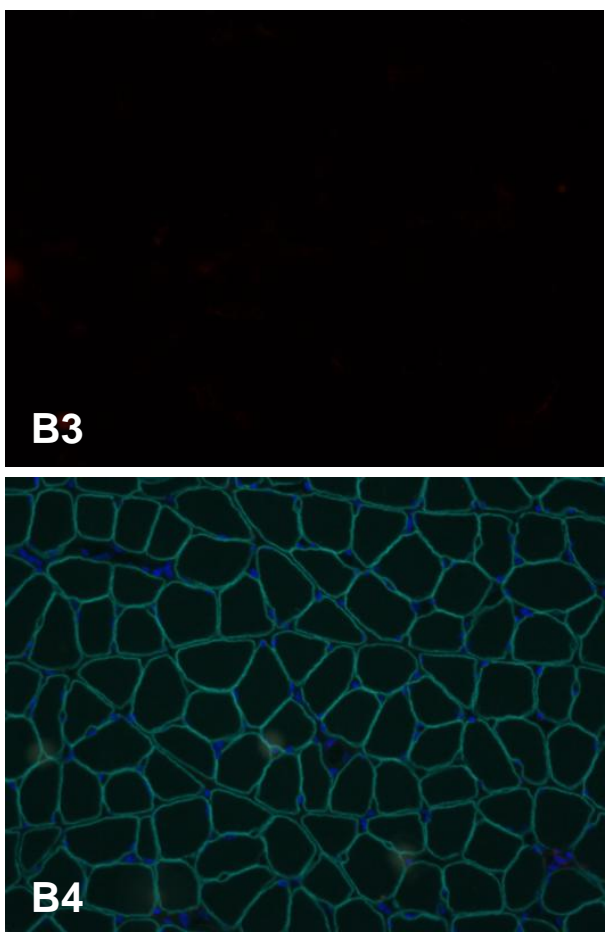

Figura 17. Fotomicrografias do músculo sóleo de animais dos grupos GC21. GC30, com lâminas processadas pelos anticorpos rabbit polyclonal antidystrophin (fluorescência verde) e mouse monoclonal [ED1] anti-CD68 (fluorescência vermelha), marcação nuclear com DAPI. 


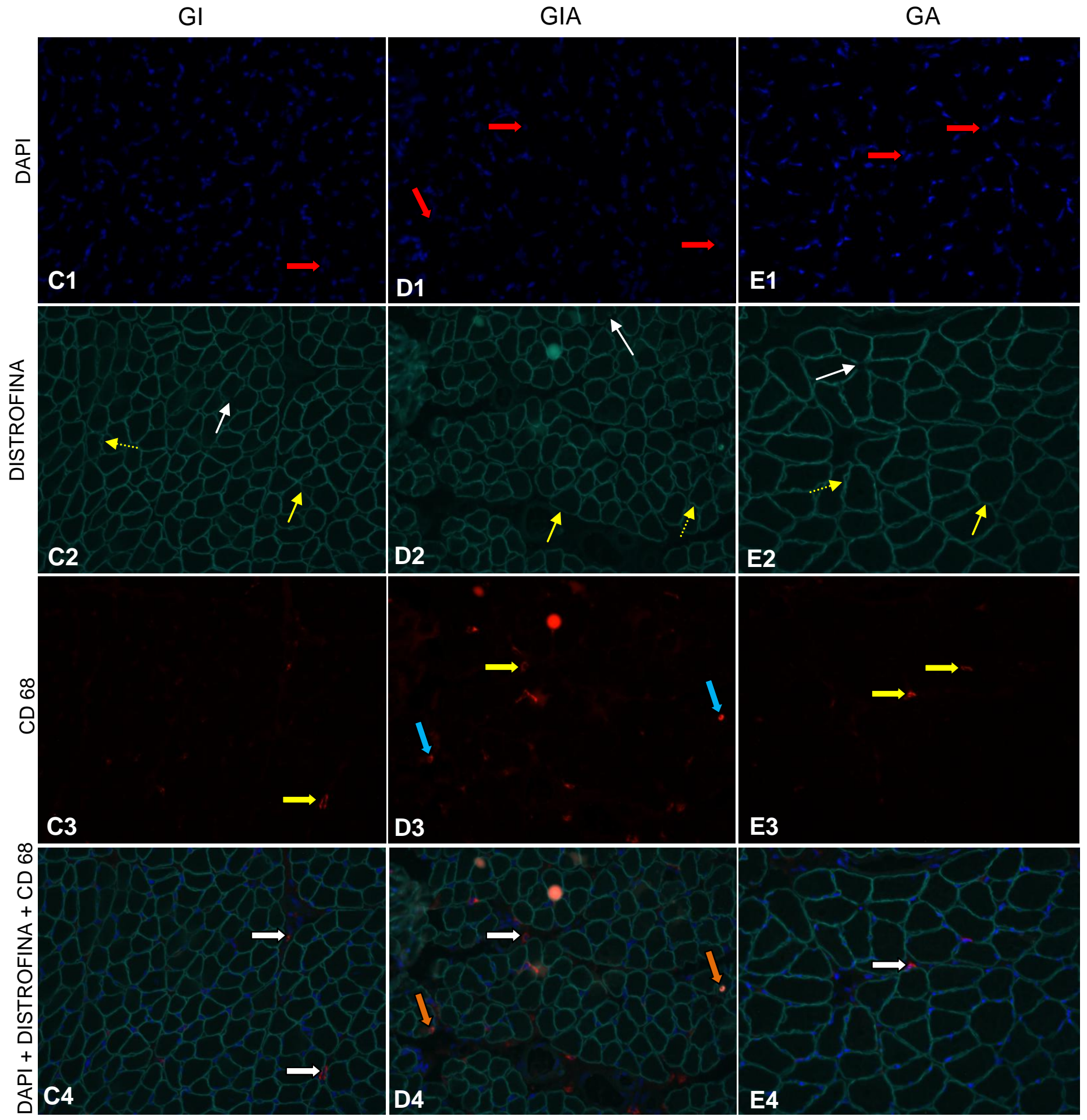

Figura 18. Fotomicrografias do músculo sóleo de animais dos grupos GI, GIA e GA, com lâminas processadas pelos anticorpos rabbit polyclonal anti-dystrophin (fluorescência verde) e mouse monoclonal [ED1] anti-CD68 (fluorescência vermelha), marcação nuclear com DAP. 
GC 21 - A1. Marcação nuclear DAPI: sem alterações; A2. Marcação para distrofina: sem alterações; A3. Marcação CD 68: sem alterações; A4. (MERGE): sem alterações

GC 30.- B1. Marcação nuclear DAPI: sem alterações; B2. Marcação para distrofina: sem alterações; B3. Marcação CD 68: sem alterações; B4. (MERGE): sem alterações

GI. - C1. Marcação nuclear DAPI (seta vermelha); C2. Marcação para distrofina: apresentou descontinuidade sarcolemal (seta branca), diminuição da marcação (seta amarela continua) e ondulações sarcolemais (seta amarela pontilhada); C3. Marcação CD 68: presença de macrófago extracelular sem a marcação do núcleo azul (seta amarela grossa). C4 (MERGE)- Presença de macrófago extracelular com seu respectivo núcleo (seta branca).

GIA - D1 marcação nuclear DAPI ( seta vermelha); D2. Marcação para distrofina: apresentou descontinuidade sarcolemal (seta branca), diminuição da marcação (seta amarela continua) e ondulações sarcolemais (seta amarela pontilhada); D3. Marcação CD 68: presença de macrófago extracelular sem a marcação do núcleo azul ( seta amarela grossa), marcação de macrófago intracelular sem a marcação do núcleo azul ( seta azul). D4 (MERGE) Presença de macrófago extracelular com seu respectivo núcleo (seta branca) e presença de macrófago intracelular (seta laranja)

GA - E1. Marcação nuclear DAPI (seta vermelha); E2. Marcação para distrofina: apresentou descontinuidade sarcolemal (seta branca), diminuição da marcação (seta amarela continua) e ondulações sarcolemais (seta amarela pontilhada); E3. Marcação CD 68: presença de macrófago extracelular sem a marcação do núcleo azul ( seta amarela grossa); E4 (MERGE) Presença de macrófago extracelular com seu respectivo núcleo (seta branca). 


\section{DISCUSSÃO}

Os resultados do presente estudo indicaram que o músculo sóleo de ratas bebês sofreram modificações citoarquiteturais significativas quando 0 alongamento manual intermitente foi usado como recurso terapêutico após 7 dias de desuso do segmento posterior direito (imobilização em flexão plantar). Em contrapartida, o alongamento manual intermitente aplicado no músculo que não sofreu desuso não foi capaz de modificar a citoarquitetura das fibras.

As principais anormalidades encontradas no grupo imobilizado e alongado foram corpos de inclusão, fragmentação, lesão tipo central core. Segundo Kannus et al. (1998) os músculos predominantes de contração lenta são mais vulneráveis ao processo de imobilização com uma indução mais rápida em suas características assim como uma profunda transformação na arquitetura e na histoquímica de suas fibras, classificadas como posturais.

A presença de núcleos centralizados representa o processo de regeneração da fibra muscular recém reparadas, pois este evento ocorre através da ativação de células precursoras da miogênese (células satélites) que irão proliferar-se e diferenciar-se para depois se fundirem as miofibras lesadas. Após o processo de fusão, a miofibra regenerada apresentará núcleos centralizados, originados das células satélites, os quais migrarão para periferia da fibra conforme ocorre a reparação da fibra muscular (HUARD 2002; ITAI; KARIYA; HOSHINO 2004; HAWKE; GARRY, 2001)

A hipomobilidade segundo estudos realizados por FRIMEL et al., (2005) e MATTIELLO-SVERZUT et al., (2006) é capaz de provocar aumento na centralização nuclear e alterações com caracteristicas degenerativo/necrótico. Os 
resultados do Gl deste trabalho, no entanto, não identificaram alterações significativas na quantidade de fibras que apresentaram núcleos centralizados ou degeneração/necrose. Acredita-se que a imobilização tenha gerado atrofia das fibras musculares por redução no conteúdo protéico, sem gerar significativa lesão nas fibras, o que corrobora com os achados encontrados por Giroux-Metges et al. (2005).

Imobilização. A hipotrofia/atrofia muscular é um dos efeitos deletérios da hipomobilidade, que neste estudo foi observados após utilização de um dispositivo de imobilização, adaptado por Benedini-Elias et al. (2009).

Segundo KANDARIAN; JACKMAN (2006) a atrofia muscular pode ocorrer devido a proteólise envolvendo três sistemas principais: sistema calpaína (via cálcio-dependente), via catepsina e sistema ubiquitina-proteossoma. O sistema calpaína é modulado pela proteína calpastatina que facilita a quebra de moléculas proteicas posteriormente disponibilizadas para a ubiquitinação (proteólise miofibrilar). A via catepsina também é ativada durante a atrofia, onde ocorre aumento de RNAm das isoformas de catepsina, protease responsável pela proteólise lisossomal com eliminação de proteínas e organelas celulares.

O sistema ubiquitina-proteossoma não degrada as miofibrilas intactas e, assim, para exercer a sua função, torna-se dependente dessas outras vias. Esse sistema envolve três enzimas principais: E1 que ativa a ubiquitina, E2 com a função de transportá-la e conjugá-la e E3 que faz a ligação específica da ubiquitina. A atuação das três enzimas é fundamental para que ocorra a proteólise já que o proteossoma só conseguirá fazer a degradação proteica quando as proteínas estiverem poliubiquitinadas. 
Para KAMIÑSKA;SZYLUK, (1996), em estudo utilizando a tenotomia como método de desuso, a hipomobilidade inibe ou reduz o fluxo aferente e eferente de informações vindo dos mecanoreceptores, o que pode levar a redução no processo de mecanotransdução, pela diminuição dos estímulos mecânicos, hipótese que pode justificar o achado das fibras com lesão tipo "central core" e alterações na imunorreatividade para os filamentos intermediários de desmina e vimentina no grupo imobilizado.

As lesões tipo "central core" como também a formação de fibras em alvo podem ocorrer devido ao aumento de níveis de cálcio nas células musculares, e que este aumento pode ativar a calpaína-3, maior protease responsável pela clivagem de proteínas no processo de degradação mediada pela ubiquitina (BAEWER et al. 2008).

É importante salientar que as fibras em alvo não são as mesmas fibras que apresentam lesão tipo "central core", o que pode ser facilmente confundido se não forem bem observadas. As fibras em alvo apresentam aumento na concentração de desmina, sugerindo uma regeneração da fibra muscular e a lesão "central core" apresenta ausência de desmina (FELLENBERG; BURGUNDER, 2003; KAMIÑSKA;SZYLUK, 1996), o que corrobora com os achados deste trabalho, demonstrados na figura 14, onde foram encontradas fibras com lesão "central core" no grupo GI, mas sem a presença de fibras em alvo.

Para esses mesmos autores supracitados, outra maneira de diferenciar estas duas alterações quanto suas características, é a observação em reações enzimáticas como NADH2-TR, com a presença de zonas de atividade oxidativa, pois o core apresenta duas zonas: uma central com ausência total de atividade 
oxidativa e glicolítica e outra periférica com atividade normal, mas nas fibras em alvo, são observadas 3 zonas: uma central sem atividade enzimática, outra intermediária que apresenta alta atividade formando um estreito anel que separa a zona central da zona periférica, onde esta ultima possui atividade enzimática normal.

Com a hipomobilidade, além das alterações encontradas através da observação com a colocaração em $\mathrm{HE}$ e imunoistoquimica para desmina e vimentina, outros achados também podem explicar os resultados para alterações na imunoistiquímica com colágenos tipo I, III e IV, coloração especial com Picrosirius e imunoistoquimica com fluorescência para distrofina e CD68.

É sabido que a inatividade, induzida pelo desuso altera as propriedades viscoelasticas do tecido muscular, como demonstrado em estudos que promoveram hipocinesia em animais (Mattiello-Sverzut et al, 2006; Polizello et al, 2009).

Outros trabalhos também identificaram aumento na quantidade de tecido conjuntivo intramuscular, principalmente em músculos imobilizados em posição encurtada (WILLIAMS; GOLDSPINK, 1984; WILLIAMS et al., 1988), com hipótese da redução nas tensões passivas no músculo imobilizado, o que poderia gerar um aumento no volume do tecido conjuntivo a fim de prevenir lesões durante uma atividade de alongamento (TABARY et al., 1972; JÄRVINEN et al., 2002, OKITA et al., 2004).

O acúmulo de tecido conjuntivo intramuscular aumentado no tecido muscular pelo desuso pode contribuir para a diminuição do fluxo sanguíneo, obliteração da luz dos capilares, e esta diminuição do fluxo nos capilares contribui 
para um aumento na quantidade de tecido conjuntivo, iniciando um ciclo vicioso (JÓZSA et al., 1990).

Segundo (GERDIN; HÄLLGREN, 1997) a imobilização pode causar aumento expressivo na concentração de ácido hialurônico - substância presente na matriz extracelular, importante para a homeostase, pois promove hidratação e lubrificação do tecido conjuntivo, conferindo estabilidade e mobilidade ao ambiente extracelular. O aumento dessa substância foi encontrado em estudo realizado por (OKITA et al., 2004), onde relacionam este evento ao aprisionamento da água causando aumento da rigidez intramuscular nos primeiros estágios da imobilização, o que pode, por sua vez, levar a alterações na configuração do colágeno após um período maior de imobilidade.

É sabido que o colágeno é a proteína mais abundante da matriz extracelular. Sua estrutura é de tripla-hélice constituída por 3 cadeias- $\alpha$ de polipeptídios. As cadeias- $\alpha$ são configuradas por repetitivas sequências de aminoácidos (glicina, prolina e hidroxiprolina) (ALBERTS et al., 2002). O tecido conjuntivo intramuscular é formado essencialmente por fibras de colágeno I e III, contendo também outros tipos de colágeno, como por exemplo, o IV e o V (LIGHT; CHAMPION, 1984). O colágeno tipo I proporciona maior força tênsil e está relacionado à maior rigidez de tecido, estando presente no perimísio e endomisio. O colágeno tipo III proporciona maior complacência e está no endomísio e no perimísio, apresentando maior quantidade no endomisio (KUROSE, 2006; AHTIKOSKI et al., 2001; SASSE JOACHIM et al 1980), e o colágeno IV auxilia na manutenção da estrutura da membrana basal (Ahtikoski et al, 2002). 
Para alguns autores Duance et al.(1977); Imamura; Imamura; Hirose-Pastor, (1999), a imobilização muscular provoca redução na movimentação entre as fibras, ocasionando em aumento da quantidade de colágeno I, a fim de promover maior resistência ao tecido. A análise do tecido conjuntivo desse trabalho vem ao encontro desta afirmativa, visto que a imobilização (Gl) provocou aumento na marcação para este tipo de colágeno. Para o colágeno tipo III, não houve alteração na marcação. E para o colágeno IV, o processo de desuso causado pela imobilização também diminuiu sua expressão.

O aumento da expressão do colágeno tipo I, confere ao tecido músculo esquelético menor flexibilidade e maior resistência à força tênsil, porém com maior fragilidade dos tecidos músculos esqueléticos, o que torna mais susceptível a lesões de estresses mecânicos longitudinais.

Outra hipótese para explicação para essas alterações, é o desequilíbrio entre as metaloproteinases da matriz (MMPs) e os tecidos inibidores da MMP (TIMPs) o que leva a alteração na quantidade de colágeno intramuscular (GIANNELLI et al., 2005; CARMELI et al., 2006). As MMPs são secretadas de forma latente e se tornam ativas lenta e gradualmente em resposta ao estresse a fim de proteger a integridade das fibras e da matriz extracelular, com uma importante função no papel de degradação, para remodelamento e manutenção da estrutura do tecido conjuntivo, além de controlar a proliferação do colágeno (MACKEY et al., 2008).

Também é sabido que os TIMPs, têm função inibitória sobre as MMP, com o objetivo de regular sua expressão no ambiente extracelular (MACKEY et al., 2008). Para Martinez et al.(2007), a MMP-2 dentro desse processo possui sua 
importância, devido a presença no tecido muscular e sua capacidade de degradar colágeno I com mais eficiências que outras colagenases, pois estudos que aplicaram modelos de desuso em animais identificaram redução na expressão de MMP-2 e aumento na expressão de TIMP-2 (GIANNELLI et al,, 2005; CARMELI et al., 2006; MARTINEZ et al, 2007).

Para Ahtikoski et al. (2002) e Takala;. Virtanen (2000), a diminuição da expressão do colágeno tipo IV no músculo em desuso, pode ser devido ao aumento das proMMP2, com uma conseqüente diminuição do nível das MMP2, desrregulando a síntese de proteína mRNA, causando essas alterações e refletindo em aumento na degradação dos colágenos tipo III e IV, o que corrobora com os estudos realizados neste trabalho.

Quanto a distrofina, existem controvérsias na literatura quanto aos achados após período de desuso, pois vários fatores estão envolvidos como idade do animal, tempo de desuso, tipo de método utilizado, se por suspensão, imobilização (gessada ou não), tenotomia. Segundo Chopard; Pons; Marini (2001), em estudo realizado com ratas fêmeas de aproximadamente $150 \mathrm{~g}$, o desuso causado pelo método de suspensão alterou a quantidade de distrofina, sendo menor entre $3 \mathrm{e}$ seis semanas. Esta alteração pode ser justificada pela diminuição de $\beta$ distroglicana, $\alpha$-sarcoglicana e $\gamma$-sarcoglicana, o que corrobora com nossos achados quanto a diminuição da marcação pela imunofluorescencia, além de ondulações e descontinuidade de distrofina em ratas bebês.

Um hipótese para a descontinuidade de distrofina além da diminuição das proteínas supra citadas, pode ser a lesão do sarcolema gerada na imobilização e juntamente com esta lesão a possibilidade de ativação de macrófagos no meio 
extracelular. É sabido que após lesão tecidual, ocorrem eventos químicos que podem ativar macrófagos neste local (TIDBALL, 2005), justificando a presença destes no grupo imobilizado.

Alongamento Manual Passivo Intermitente após Imobilização. Muitas técnicas na prática clínica são utilizadas após procedimentos de imobilização de um membro, seja ele por meio de tala gessada, fixadores externos, bandagens semi-rigidas, através de alongamentos mantidos, intermitentes, hidroterapia, exercícios excêntricos, com o objetivo de recuperar a cinesiofuncionalidade o mais próximo possível do estágio pós lesão. Neste trabalho abordamos o alongamento manual passivo intermitente para analisar as respostas do tecido músculo esquelético a este estímulo.

É sabido que o alongamento passivo pode causar lesões nas fibras musculares, levando a degeneração e subseqüentemente à regeneração (Benedini-Elias et al., 2013; Cornachione et al., 2013; Cação-Benedini et al., 2013; YANG et al, 1997).

Para os autores Kovanen et al. (1988), Ahtikoski et al. (2003), acredita-se que a simulação de hipocinesia fragiliza as miofibras do músculo esquelético, e a adição de exercício ao retorno da sobrecarga pode causar lesões sarcolemais.

No entanto, o protocolo utilizado neste estudo, não apresentou diferenças estatísticas ( $p>0.05$ ) entre os grupos GA com os grupos controle (GC21 - GC30) em relação as alterações histopatológicas (fragmentação, central core e corpos de inclusão) como também imunorreatividade para desmina e vimentina, colágenos tipo I, III e IV, distrofina e CD 68. As alterações com diferenças estatísticas em relação aos grupos controles (GC21; GC30), envolvendo o alongamento manual 
passivo intermitente após os procedimentos de imobilização, ocorreram entre os grupos (GIA x GC30) para imunorreatividade da desmina, mas não houve essa diferença para o grupo GC21. Este achado pode esclarecer uma possível hipótese sobre o efeito do AMPI no estágio inicial para reversão dos efeitos deletérios da imobilização, pois quando comparados os grupos GIA e GC30 para imunorreatividade da vimentina, não houve diferença estatística.

Ao observar essas duas variáveis (desmina e vimentina), pode-se deduzir que a imobilização resulta em alterações nas estruturas do tecido músculo esquelético, no entanto, após o estímulo do alongamento, os filamentos intermediários de vimentina respondeu de maneira satisfatória e a curto prazo (3 dias), auxiliando na recuperação devido a sua função, como mencionado anteriormente, ser a orientação no posicionamento do núcleo e do fuso mitótico (CHOU; ROSENVAR; GOLDMAN, 1989), mas que, nos grupos imobilizados (Gl) não foram encontrados núcleos centralizados, pois o tempo de desuso não foi satisfatório para a observação de tais alterações, no entanto, quando analisado estatísticamente os efeitos do Gl e a resposta do AMPI após o desuso, houve uma reversão nessa variável (imunorratividade de vimentina) para os parâmetros do grupo controle GC30, com baixo índice de lesão conforme observado nos resultados da densidade de macrófagos entre os grupos Gl e GIA, pois estatísticamente esses grupos não apresentaram diferença.

Se essa diferença fosse estatisticamente observada entre esses dois grupos, levantar-se-ia a hipótese que o AMPI causaria lesões músculo esquelética significativas, retardando a recuperação desse tecido, mas este achado não foi observado neste estudo tanto para o GIA como GA. 
Foram observadas no GIA através das imagens com imunofluorêscencia para distrofina e CD 68 , diminuição, ondulações e descontinuidade da marcação de distrofina e presença de macrófagos, mas essas alterações também foram observadas no grupo imobilizado e com menor intensidade no GA. Para Kääriäinen et al. (2000), o alongamento passivo, pode provocar descontinuidade de componentes da MEC ou do sarcolema e desencadear uma cascata de reações bioquímicas em virtude deste estímulo. No entanto, as alterações histopatológicas entre os grupos GI e GIA, não apresentaram diferenças estatísticas, assim como a quantidade de macrófagos entre esses mesmos grupo.

Esses achados sustem que o AMPI não causou lesões ao tecido músculo esquelético significativas após o desuso, porém é importante destacar os dados entre os grupos GC30 x GIA; GC21 x GIA (para filamentos intermediários de vimentina e desmina), o que evidencia estágios iniciais da reversão dos efeitos deletérios da imobilização.

Essa influência mecânica no tecido músculo esquelético, ficou evidente neste estudo, levando em consideração o protocolo adotado.

O desuso segundo estudo realizado por KAMINSKA (1996), através da tenotomia, provoca alterações como mudanças enzimáticas e na estrutura do musculo sóleo, tendo como alguns resultados, a diminuição de mitocôndrias, ruptura de miofibrilas, desorganização no sarcomero e linha Z.

Em músculo imaturo tanto a desmina como vimentina coexistem na região da linha Z, sendo a vimentina sintetizada primeiro e após processo de maturação e maior desenvolvimento a desmina aumenta sua síntese e função (GARD; LAZARIDE, 1980; GRANGER; LAZARIDE, 1979). 
É sabido que o alongamento exerce estímulos tanto no sentido longitudinal como transversal na fibra muscular (GROUNDS; WHITE, 2005) e este estímulo pode provocar alterações na região da linha $Z$ e sarcômeros, afetando os filamentos intermediários de desmina e vimentina, como também lesão no sarcolema, causando a descontinuidade da distrofina. Estes achados corroboram com os dados encontrados em nossos estudos.

No entanto ainda não está claro na literatura, a ordem que acontece esta desorganização na região dos sarcômeros e linha Z, se antecedem ou precedem as alterações observadas nos filamentos intermediários de desmina, vimentina e no costâmero, na distrofina.

Na reparação muscular, esses filamentos são importantes para reorganizar a formações das estruturas das novas fibras musculares como posicionamento de núcleos, mitocôndrias e organização sarcomérica (GALLANT et al, 1992) e desta maneira dar continuidade ao processo de recuperação muscular. 
CONCLUSÃO 


\section{CONCLUSÃO}

Considerando o protocolo de alongamento utilizado em ratas bebês em desenvolvimento pós-natal, é possível concluir que:

1. O alongamento manual passivo intermitente aplicado no músculo saudável não determina alterações citoarquiteturais significativas, seja nos elementos da matriz extracelular, nos elementos do costâmero ou dos filamentos intermediários aqui analisados;

2. O músculo sóleo após ter sofrido imobilização por um período de 7 dias e remobilização pelo alongamento manual intermitente sofreu modificações como micro-lesões e anormalidades degenerativas em estruturas do costâmero, da matriz extracelular e em alguns filamentos intermediários. Esse conjunto de alterações sugere que a transmissão de forças que ocorre entre os compartimentos intra e extracelular fica comprometida no músculo imobilizado.

3. Três dias de remobilização após imobilização proporcionam o início da fase de reorganização tecidual porém não são suficientes para restabelecer seu estado de integridade citoarquitetural. Um maior período de tempo é necessário para concluir os eventos que adaptativos estruturais. 
REFERÊNCIAS 


\section{REFERÊNCIAS BIBLIOGRÁFICAS}

AGBULUT, O; NOIREZ, P; BEAUMONT, F; BUTLER-BROWNE, G. Myosin heavy chain isoforms in postnatal muscle development of mice. Biology of the Cell, Colchester, v. 95, n. 6, p. 399-406, 2003.

ADAMS, G. R; HADDAD, F.; BODELL, P. W; TRAN, P. D; BALDWIN, K. M. Combined isometric, concentric, and eccentric resistance exercise prevents unloading-induced muscle atrophy in rats. Journal of Applied Physiology. Washington, v.103,2007.

AHTIKOSKI, A. M.; KOSKINEN, S. O.; VIRTANEN, P.; KOVANEN, V.; RISTELI, J.; TAKALA, T. E. Synthesis and degradation of type IV collagen in rat skeletal muscle during immobilization in shortened and lengthened positions. Acta Physiologica Scandinavica. Stockholm, v. 4, n. 177, 2003.

BALDWIN, K. M. et al. The effects of space flight on the contractile apparatus of antigravity muscles: implications for aging and deconditioning. Journal of gravitational physiology. Galileo Foundation, v. 1, p. 8-11, 1994.

BENEDINI-ELIAS, P. C.; MORGAN, M. C.; GOMES, A. R.; MATTIELLO-SVERZUT, A. C. Changes in postnatal skeletal muscle development induced by alternative immobilization model in female rat. Anatomical Science International, Carlton, v. 84, n. 3, p. 218-25, 2009.

BURKHOLDER, T. J. Mechanotransduction in skeletal muscle. Frontiers in bioscience : a journal and virtual library. Tampa, v. 12, p.174-191, 2008.

CAIOZZO, V. J. Plasticity of skeletal muscle phenotype: mechanical consequences. Muscle \& Nerve. New York, v. 26, n. 6, 2002. 
CAIOZZO, V. J.; MICHAEL J. BAKER, M. J.; BALDWIN, K. M. Modulation of myosin isoform expression by mechanical loading: role of stimulation frequency. Journal of applied physiology. Washington, v. 82, n.1, p. 211-218, 1997.

CAIOZZO, V. J.; BAKER, M. J.; BALDWIN, K. M. Novel transitions in MHC isoforms: separate and combined effects of thyroid hormone and mechanical unloading. Journal applied of physiology. Washington, v. 85 , n. 6 , p. 2237-2248, 1998.

CARVALHO, C. M. M.; SHIMANO, A. C.; VOLPON, J. B. Efeitos da imobilização e do exercício físico em algumas propriedades mecânicas do músculo esquelético. Revista Brasileira de Engenharia Biomédica. São Paulo, v. 18, 2002.

CARVALHO, L. C.; SHIMANO, A. C.; PICADO, C. H. Estimulação elétrica neuromuscular e o alongamento passivo manual na recuperação das propriedades mecânicas do músculo gastrocnêmio imobilizado. Acta Ortopédica Brasileira. São Paulo, v. 16, n. 3, p. 161-164, 2008.

COSTA, M.L.; ESCALEIR, R.; CATALDO, A.; OLIVEIRA F.; MERMELSTEIN C.S. Desmin: molecular interactions and putative functions of the muscle intermediate filament protein. Brazilian Journal of Medical and Biological Research) 37: 1819-1830. 2004.

CHARGE, S. B.; RUDNICKI, M. A. Cellular and molecular regulation of muscle regeneration. Physiological reviews, Washington, v. 84, n. 1, p. 209-238, 2004.

CHOCKALINGAM, P. S.; CHOLERA, R.; OAK, S. A.; ZHENG, Y.; JARRETT, H. W.; THOMASON, D. B. Dystrophin-glycoprotein complex and Ras and Rho GTPase signalling are altered in muscle atrophy. American journal of physiology. Cell physiology. Bethesda, v. 283, p. 500-511, 2002. 
CHOU, YING-HAO, ROSEVEAR, ELLEN; GOLDMAN, ROBERT D.Phosphorylation and disassembly of intermediate filaments in mitotic cells. Proc. Nati. Acad. Sci. Cell BiologyVol. 86, pp. 1885-1889, 1989.

CHEN, T. C.; LIN, Kun-Yi; CHEN, Hsin-Lian; LIN ,Ming-Ju ; NOSAKA, K. Comparison in eccentric exercise-induced muscle damage among four limb muscles. European Jounal Applied Physiology, v. 111, p. 211-223, 2011.

CLARKSON, P.M.; HUBAL, M.J. Exercise-induce muscle damage in humans. American Journal Physiology Rehabilitation, 2002.

Clarkson, P.ME, Newham, D.J. Association between muscle soreness, damage, and fatigue. Advances in Expimetal Medicine and Biology, v.384, p.457-469, 1995

CLEBIS, N. K.; NATALI, M. R.M. Lesões musculares provocadas por exercícios excêntricos. Revista Brasileira Ciência e Movimento, Brasília, v.9, n.4, p.47-53, outubro, 2001.

COOPER, R.R. Alterations during immobilization and regeneration of skeletal muscle in cats. Journal of Bone and Joint Surgery, Bonton, v.54, p.919-953, 1972.

CORNACHIONE, A.; CAÇÃO-BENEDINI, L. O.; SHIMANO, M. M.; VOLPON, J. B.; MARTINEZ, E. Z.; MATTIELLO-SVERZUT, A. C. Morphological comparison of different protocols of skeletal muscle remobilization in rats after hindlimb suspension. Scandinavian Journal of Medicine \& Science in Sports. Copenhagen, v.18, n. 4, 2008.

COUTINHO, E. L.; DELUCA, C.; SALVINI, T. F.; VIDAL, B. C. Bouts of passive stretching after immobilization of the rat soleus muscle increase collagen macromolecular organization and muscle fiber area. Connect Tissue Research. Philadelphia, v. 47, 2006 
COUTINHO, E. L.; GOMES, A. R. S.; FRANÇA, C. N.; OISHI, J.; SALVINI, T. F. Effect of passive stretching on the immobilized soleus muscle fiber morphology. Brazilian of Journal of Medical and Biological Research. São Paulo, v. 37, n. 12, p. 1853-1861, 2004.

COUTINHO, E. L.; GOMES, A. R. S.; FRANÇA, C. N.; OISHI, J.; SALVINI, T. F. A new model for the immobilization of the rat hindlimb. Brazilian Journal of Medical and Biological Research. São Paulo, v. 35, p. 1329-1332, 2002.

DAPSON, R.W.; FAGAN, C.; KIERNAN, J.A.; WICKERSHAM, T.W . Certification procedures for sirius red F3B (Cl 35780, Direct red 80). Biotechnic \& Histochemistry, 86(3): 133-139. 2011

DURIGAN, J. L. Q.; CANCELLIERO, K. M.; DIAS, C. K. N.; SILVA, C. A.; GUIRRO, R. R. J.; POLACOW, M. L. O. Efeitos da estimulação elétrica neuromuscular sobre o membro posterior imobilizado de ratos durante 15 dias: Análises metabólicas e morfométricas. Revista Brasileira de Fisioterapia. São Carlos, v. 10, n. 3, 2006.

FERREIRA, R.; NEUPARTH, M.J.; ASCENSÃO,A.; MAGALHÃES,J. DURTE, J.; AMADO, F. Atrofia muscular esquelética. Modelos expreimentas, manifestações teciduais e fisiopatologia. Revista Portuguesa de Ciência do Desporto, v. 4, n.3, p. 94-111, 2004.

FOSCHINI,D; PRESTES J.; CHARRO, M. A. Relação entre exercício físico, dano muscular e dor muscular de início tardio. Revista Brasileira de Cineantropometria \& Desempenho Humano, v.9, n.1, p.101-106, 2007.

FRANKE, WERNER W.; SCHMID, ERIKA; OSBORNT, MARY; WEBERT, KLAUS. Different intermediate-sized filaments distinguished by immunofluorescence microscopy. Proc. Natl. Acad. Sci. Cell Biology Vol. 75, No. 10, pp. 5034-5038, October 1978. 
FRIDEN, J.; LIEBER, R.L. Segmental muscle fiber lesions after repetitive eccentric contration. Cell Tissue Research, 1998.

FRIMEL, T. N.; KAPADIA, F.; GAIDOSH, G. S.; LI, Y.; WALTER, G. A.; VANDENBORNE, K. A model of muscle atrophy using cast immobilization in mice. Muscle \& Nerve, New York, v. 32, n. 5, p. 672-674, 2005

GAJDOSIK, R. L.; ALLRED, J. D.; GABBERT, H. L.; SONSTENG, B. A. A stretching program increases the dynamic passive length and passive resistive properties of the calf muscle-tendon unit of unconditioned younger women. European Journal of Applied Physiology, Berlin, v. 99, p. 449-454, 2007.

GAMRIN, L.; BERG, H. E.; ESSEN, P.; TESCH, P. A.; HULTMAN, E.; GARLICK, P. J.; MCNURLAN, M. A.; WERNERMAN, J. The effect of unloading on protein synthesis in human skeletal muscle. Acta Physiologica Scandinavica. Stockholm, v. 163, n. 4, p. 369-377, 1998.

GOLDSPINK, G. Changes in muscle mass and phenotype and the expression of autocrine and systemic growth factors by muscle in response to stretch and overload. Journal of anatomy. London, v. 194, p. 323-334, 1999.

GOMES, A. R. S.; CORNACHIONE, A.; SALVINI, T. F.; MATTIELLO-SVERZUT, A. C. Morphological effects of two protocols of passive stretch over the immobilized rat soleus muscle. Journal of Anatomy. London, v. 210, 2007.

GOMES, A. R. S.; COUTINHO, E.L.; FRANÇA, C.N.; POLONIO, J.; SALVINI, T.F. Effect of one stretch a week applied to the immobilized soleus muscle on rat muscle fiber morphology. Brazilian of Journal of Medical and Biological Research, São Paulo, v. 37, n. 10, p. 1473-1480, 2004. 
GONDRET, F.; SYLVIE COMBES, S.; LEFAUCHEUR, L.; LEBRET, B. Effects of exercise during growth and alternative rearing systems on muscle fibers and collagen properties. Reproduction Nutrition Development. Paris, v. 45, p. 69-86, 2005.

HAMILL, O. P.; MARTINA, C. B. Molecular basis of mechanotransduction in living cells. Physiological Reviews. United States, v. 81, p. 685-740, 2001.

HEBERT, Sizínio; XAVIER, Renato. Ortopedia e Traumatologia: Princípios e prática. 4.ed. Porto Alegre: Artemed, 2009.

HERRMANN, H.; BÄR, H.; KREPLAK, L.; STRELKOV, S. V.; AEBI, U. Intermediate filaments: from cell architecture to nanomechanics. Nature Reviews Molecular Cell Biology. London, v. 8, 2007.

HESLINGA, J. W.; KRONNIE, G.; HUIJING, P. A. Growth and immobilization effects on sarcomeres: a comparison between gastrocemius and soleus muscle of the adult rat. European journal of applied physiology. Berlin, v. 70, p. 49-57, 1995.

HWANG, J. H.; YUN-JU, R. A.; LEE,K. M.; LEE, J. Y.; GHIL, S. H. Therapeutic Effect of Passive Mobilization Exercise on Improvement of muscle Regeneration and Prevention of Fibrosis After Laceration Injury of Rat. Archives of physical medicine and rehabilitation. Philadelphia, v. 87, p. 20-26, 2006.

IVASKA, JOHANNA; PALLARI, HANNA-MARI; NEVOA, JONNA; ERIKSSON, JOHN E. Novel functions of vimentin in cell adhesion, migration, and signaling. Experimental cell reserarch v.313, p.p.2050 -2062, 2007.

JÄRVINEN, T. A.; JÄRVINEN, T. L.; KÄÄRIÄINEN, M.; KALIMO, H.; JÄRVINEN, M. Muscle injuries: biology and treatment. The American Journal of Sports Medicine. Baltimore, v. 33, n. 5, 2005. 
JÄRVINEN, T. A.; JOZSA, L.; KANNUS, P.; JARVINEN, T. L.; JARVINEN M. Organization and distribution of intramuscular connective tissue in normal and immobilized skeletal muscles. Journal of Muscle Research and Cell Motility, Dordrecht, v. 23, n. 3, p. 245-254, 2002.

JÓZSA,L.; KANNUS,P; THÖRING, J.; REFFY, A; JÄRVINEM, M; KVIST, M. The effects of tenotomy and immobilization on intramuscular connective tissue. Journal Bone Joint Surgery, Boston, v.72, n.2, p.293-297, 1990.

KANNUS, P.; JOZSA, L. M.; KVIST, M.; VIENO, T.; JARVINEN, T. L.; NATRI, A.; JARVINEN, M. Free mobilization and low-to high-intensity exercise in immobilization-induced muscle atrophy. Journal of applied physiology. Washington, v. 84, p.1418-1424, 1998.

KASPER, C. E. et al. Alterations in skeletal muscle related to impaired physical mobility: an empirical model. Research in Nursing and Health, New York, v. 16, p. 265-273, 1993.

KELLY, A. E.; RUBINSTEIN, N. A. The diversity of muscle fiber types and its origin during development. In: ENGEL, A. G.; FRANZINI-ARMSTRONG, C. (eds.). The International Journal of Oral Myology. New York: McGraw-Hill, v. 4, 1994.

KISNER, C.; COLBY, L. A. Exercícios terapêuticos: fundamentos e técnicas. $3^{\text {a }}$ ed, São Paulo: Manole, cap 5, 1998.

KJÆR, M. Role of Extracellular Matrix in Adaptation of Tendon and Skeletal Muscle to Mechanical Loading. Physiological Reviews. Washington, v. 84, p. 649-698, 2004. 
KOVANEN, V. Intramuscular extracelular matrix: complex enviroment of muscle cells. Exercise and Sports Science Reviews. Amherst, v. 30, n. 1, p. 20-25, 2002.

LARSEN, M.; ARTYM, V. V.; GREEN, A. J.; YAMADA, K. M. The matrix reorganized: extracellular matrix remodeling and integrin signaling. Current Opinion in Cell Biology. Philadelphia, v. 18, n. 5, p. 463-471, 2006.

LAZARIDES, E. Intermediate filaments: A chemically heterogeneous developmentally regulated class of protein. Annu Rev Biochem, n. 51, p. 219250, 1982.

LIEBER, R. L.; LEONARD, M. E.; BROWN-MAUPIN, C. G. Effects of muscle contraction on the load-strain properties of frog aponeurosis and tendon. Cells Tissues Organs. Switzerland, v.1666, 2000.

LOUGHNA, PAUL T.; BROWNSON, CAROL. Two myogenic regulatory factor transcripts exhibit muscle-specific responses to disuse and passive. stretch in adult rats Federation of European Biochemical Societies, FEBS Letters, n. 390, p. 304-306,1996.

LOVERING, RICHARD M.; DE DEYNE, PATRICK G. Contractile function, sarcolemma integrity, and the loss of dystrophin after skeletal muscle eccentric contraction-induced injury. AJP-Cell Physiology, v.286, FEBRUARY 200

MALM, C.; LENKEI, R.; SJÖDIN, B. Effects of eccentric exercise on the immune system in men. Journal Applied Physiology, v.86, p.461-468,1999 
MERCIER, J.; PEREZ-MARTIN, A; BIGARD, X; VENTURA, R. Muscle plasticity and metabolism: effects of exercise and chronic diseases. Molecular Aspects of Medicine, Oxford, v.20, p.319-373, 1999.

MAYHEW,T.;ROTHSTEIN,J.M.; FINUCANE, S.D.; LAMB, R.B. Muscular adaptation to concentric and eccentric at equal power levels. Medicine Science of Sports Exercise, Madson, v.27, n.6, 1995.

MATTIELLO-SVERZUT, A. C.; CARVALHO, L. C.; CORNACHIONE, A.; NAGASHIMA, M.; NEDER, L.; SHIMANO, A. C. Morphological effects of electrical stimulation and intermittent muscle stretch after immobilization in soleus muscle. Histology Histopathology. Murcia, v. 21, 2006.

NATALLI, L.H.; SILVA T.S.; CIENA, A.P.; PADOIN, M.J.; ALVES, E.P.B.; ARAGÂO, F.A.; BERTOLINI, G.R. Efeitos da corrida em esteira em músculos sóleos de ratos encurtados por imobilização. Revista Brasileira Medicina Esportiva, v.14, n.6, nov-dez, 2008.

NORMAN, T.L. et al. Aerobic exercise as a countermeasure for microgravityinduced bone loss and muscle atrophy in a rat hindlimb suspension model. Aviation, space, and environmental medicine, Washington, v. 71, p. 593-598, 2000.

OKITA, M.; YOSHIMURA, T.; NAKANO, J.; SAEKI, A.; UEHARA, A.; MINESHITA, A.; EGUCHI, K. Effects of short duration stretching on disuse muscle atrophy in immobilized rat soleus muscle. Journal of the American Physical Therapy Association. New York, v. 4, p. 1-5, 2001

OUSTANINA, S.; HAUSE, G.; BRAUN, T. Pax7 directs postnatal renewal and propagation of myogenic satellite cells but not their specification. The EMBO journal, Oxford, v. 23, n. 16, p. 3430-9, 2004. 
PATTULLO, M. C.; COTTER, M. A.; CAMERON, N. E.; BARRY, J. A. Effects of lengthened immobilization on functional and histochemical properties of rabbit tibialis anterior muscle. Experimental physiology. Cambridge, v. 77, p. 433-442, 1992.

PETTE, D.; STARON, R. S. Myosin isoformas, muscle fiber types and transitions. Microscopy research and thechinique. New York, v. 50, p. 500-509, 2000.

PETTE, D.; PEUKER, H.; STARON, R. S. The impact of biochemical methods for single muscle fiber. Acta Physiologica Scandinavica. Stockolm, v. 166, p. 261-277, 1999.

PEUKER, H.; CONJARD, A.; PETTE, D. Alpha-cardic-like myosin heavy chain as an intermediate between $\mathrm{MHClla}$ and $\mathrm{MHCl}$ beta in transforming rabbit muscle. The American Journal of Physiology, v.274, n.3, p.595-602, 1998.

PRASARTWUTH, O; ALLEN, T.J.; BUTLER, J.E.; GANDEVIA, S.C.; TAYLOR, J.L. Length-dependent changes in voluntary activation, maximum voluntary torque and twitch responses after eccentric damage in humans. Journal Physiology; v. 571, p. 243-252, 2006.

PROSKE, U.; MORGAN, D. L. Muscle damage from eccentric exercise: mechanism, mechanical signs, adaptation and clinical applications. The Journal of physiology, London, v. 537, p. 333-345, 2001

PUNKT, K.; NAUPERT, A.; ASMOSSEN, G. Differentiation of rat skeletal muscle fibres during development and ageing. Acta Histochemica, Jena Gustav Fischer Verlag, v. 106, n. 2, p. 145-54, 2004

Roth, S.M.; Martel, G.F.; Rogers, M.A. Muscle biopsy and muscle fiber hipercontration: a brief review. European Journal of Applied Physioly, vol. 83, p. 239-245, 2000. 
SAKA, T.; AKOVA, B.; YAZICI, Z.; SEKIR, U.; GUÜR, H.; OZARDA, Y. Difference in the magnitude of muscle damage between elbow flexors and knee extensors eccentric exercises. Jounal Sports Scienci Medicine v.8, p.107115,2009 .

SCHUENKE, Mark D.; Kopchick, John J.; Hikida, Robert S.; Kraemer, William J.; Staron, Robert S.. Effects of growth hormone overexpression vs. Growth hormone receptor gene disruption on mouse hindlimb muscle fiber type composition. SienciDirect, v.18, p.479-486, 2008.

SERRÃO, F. V.;FOERSTER, B.; PEDRO, V. M.; TANNÚS, A.; SALVINI, T. F. Análise do torque isométrico e da atividade elétrica após lesão muscular induzida por exercício excêntrico em humanos. Revista Brasileira Fisioterapia, vol. 8, n. 3, p. 179-185,2004.

SHRIER, I. Stretching before exercise does not reduce the risk of local muscle injury: a critical review of the clinical and basic science literature. Clinical Journal of Sports Medicine;v. 9; p.;221-27,1999).

SILVA, C.; GUIRRO, R.; POLACOW, M.; CANCELLIERO, K.; DURIGAN, J. Rat hindlimb joint immobilization with acrylic resin orthoses. Brazilian Journal of Medical and Biological Research. São Paulo, v. 39, n. 7, p. 979-985, 2006.

SULLIVAN, V. K.; POWERS, S. K.; CRISWELL, D. S.; TUMER, N.; LAROCHELLE, J. S.; LOWENTHAL, D. Myosin heavy chain composition in young and old rat skeletal muscle: effects of endurance exercise. Journal applied of physiology, Washington, v. 78, n. 6, p. 2115-20, 1995. 
TABARY, J.C.; TABARY, C.; TARTIEU, C.; TARTIEU, G.; GOLDSPINK, G. Physiological and strutural changes in the cat's soleus muscle due to immobilization at different length by plaster casts. Journal Physiology, v.224, p231-325, 2000.

TABARY, J. C.; TABARY, C.; TARTIEU, C.; TARDIEU, G.; GOLDSPINK, G. Physiological and structural changes in the cat's soleus muscle due to immobilization at different length by plaster casts. The Journal of Physiology, London, v. 224, p. 231-244, 1972.

TALMADGE, R. J. Myosin heavy chain isoform expression following reduced neuromuscular activity: potential regulatory mechanisms. Muscle \& Nerve. New York, v. 23, p. 661-679, 2000.

TAKEKURA, $H$. et al. Eccentric exercise-induced morphological changes in the membrane systems involved in excitation-contration coupling in rat skeletal muscle. Journal of Physiology, London, v. 533, n. 2, p. 571-583, 2001.

THOMPSON, L.V. Skeletal muscle adaptations with age, inactivity and therapeutic exercises. The Journal of Orthopedic, Sports and Physical Therapy, v.32, n.2, p44-57, 2002.

WARREN, G. L.; HAYES, D. A.; LOWE, D. A.; WILLIAMS, J. H.; ARMSTRONG, R. $B$. Eccentric contraction-induced injury in normal and hindlimb-suspended mouse soleus and EDL muscles. Journal of Applied Physiology. Washington, v. 77, n. 3, p. 1421-1430, 1994.

WELDON, S. M. ; HILL, R. H. The efficacy of stretching for prevention of exercise-related injury: a systematic review of literature. Manual Therapy, Edinburgh, v. 8, n. 3, p. 141-150, 2003. 
WILLIAMS, P. E.; GOLDSPINK, G. Connective tissue changes in immobilised muscle. Journal of anatomy, London, v. 138, n. 2, p. 343-50, 1983.

WILLIAMS, P. E.; GOLDSPINK, G. The effect of immobilization on the longitudinal growth of striated muscle fibres. Journal of anatomy, London, v. 116, p. 45-55, 1973.

WILMORE, J.H.; COTILL, D.L. Physical energy: fuel metabolism. Nutrition reviews, v.59 (1 Pt 2): S13-6, 2001.

WILLIAMS, P. E. Effect of intermittent stretch on immobilised muscle. Annals of the rheumatic diseases, London, v. 47, p. 1014-1016, 1988.

YATES, D. T.; MACKO, A. R.; NEARING, M.; CHEN, X.; RHOADS, R. P.; LIMESAND, S. W. Developmental Programming in Response to IntrauterineGrowth Restriction ImpairsMyoblast Function and Skeletal MuscleMetabolism. v.12. April, 2012. 
ANEXOS 


\section{ANEXOS}

ANEXO A. Cópia do documento de confirmação da submissão do artigo intitulado

"Three days of rehabilitation by intermittent stretching does not minimize the effects of disuse on elements of the extracellular matrix and intermediate filaments of the soleus muscle of weanling rats" submetido no Brazilian Journal of Medical and Biological Research em Maio de 2014.
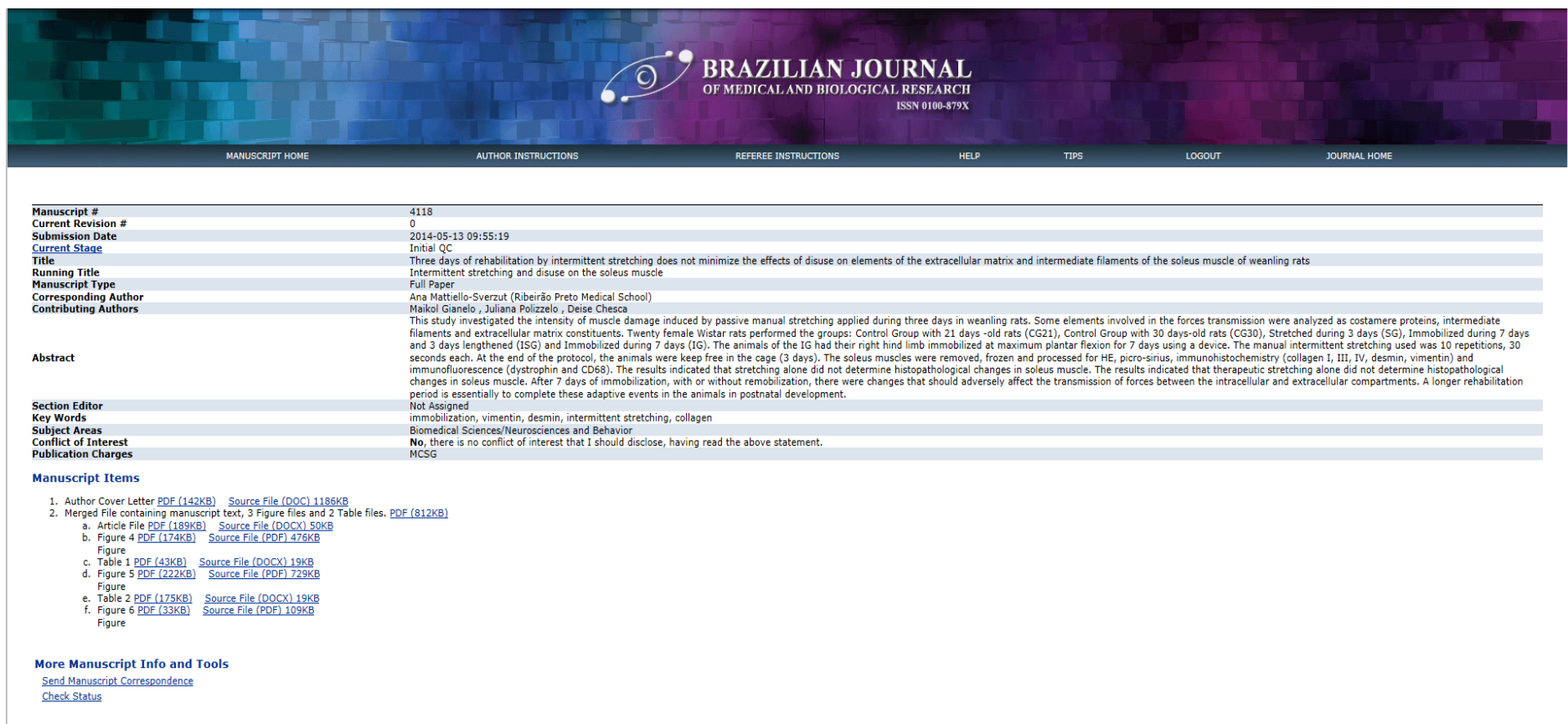